\title{
Major factors influencing antioxidant contents and antioxidant activity in grapes and wines
}

\author{
Jaromír Lachman \\ Miloslav Šulc \\ Kateřina Faitová \\ Vladimír Pivec
}

Department of Chemistry, Faculty of Agrobiology, Food and Natural Resources, Czech University of Life Sciences, Prague, Czech Republic

Correspondence: Jaromír Lachman Department of Chemistry, Faculty of Agrobiology, Food and Natural Resources, Czech University of Life Sciences, Kamýcká 129, 165 21 Prague 6 - Suchdol, Czech Republic

Tel +420224382 717

Fax +42023438I 840

Email lachman@af.czu.cz

\begin{abstract}
Phenolic compounds in wines, especially in red wines, possess strong antioxidant activity, have the largest effect in decreasing atherosclerosis by both hypolipemic and antioxidant mechanisms. The long-term uptake of red wine has a positive impact on antioxidant activity (AA) of blood plasma in rats in vivo and increases AA by 15\%-20\% compared to a control group. In the article the effect of total phenolics (TP), total anthocyanins (TA), individual anthocyanins, procyanidins and phenolics contained in red grapes, musts, grape seeds and skins and wines on the AA is discussed. Significant impact of varieties, viticultural regions and locations, climate conditions and vintage has been shown. Likewise, the ways and individual stages of the vinification technology process, and storage conditions affect color, TP, TA, and AA and health aspects of produced wines. Resveratrol, another free radical scavenger mainly contained in the skins of grapes, inhibits the risk of cardiovascular diseases. Higher amounts of trans-resveratrol (RES) have been found in wines from cool and wet climate regions and lesser amounts are typical for warm and dry regions. Changes in the TP content and AA affected by grape variety, vineyard location and winemaking process in white and blue varieties from different vineyards of the Czech Republic were studied. Significant differences in TP among varieties were found. Analysis of variance showed statistically high differences among red and white wines and growing locations. Wines differed significantly in TP content and AA increased significantly during the winemaking process. Statistically significant differences in AA values were found among growing areas, wines and varieties. Significant positive correlations between TP and AA were determined. Total antioxidant status (TAS) of white and red wines (white and blue vine varieties) determined by DPPH and ABTS assays revealed significant differences in AA between white and red wines. Moreover, differences were ascertained between individual varieties of red wine. The results obtained supported the assumption that variety plays a considerable role in TAS; the blue vine varieties showed a much higher TAS. Analysis of variance in AA showed statistically high significance between red and white wines. AA increased during the winemaking process, the highest increase was determined during fermentation and maturation stages of red wine.
\end{abstract}

Keywords: wine, grape, antioxidants, antioxidant activity, DPPH, ABTS, extrinsic and intrinsic factors

\section{Introduction}

It was recently determined that moderate red wine consumption improves endothelial function in normal volunteers and oxidative stress in patients with an acute coronary syndrome. ${ }^{1}$ The "antioxidant power" of a food is an expression of its capability both to defend the human organism from the action of free radicals and to prevent degenerative disorders deriving from persistent oxidative stress. ${ }^{2}$

Many epidemiological studies have shown a correlation between diets that are not well-balanced and coronary heart diseases, a few types of cancer and diabetes. ${ }^{3,4}$ Red wine is particularly rich in polyphenol substances compared to white wine. ${ }^{5}$ Red wines raise plasma high-density lipoprotein (HDL)-cholesterol, plasma triglyceride, 
total cholesterol concentrations and wine polyphenols may be particularly useful in preventing Alzheimer's disease. ${ }^{6}$ Other mechanisms involving phenolics, such as inhibition of platelet aggregation and influence on prostaglandin synthesis, are also recognized as contributory in preventing cardiovascular diseases. ${ }^{7}$ The polyphenolic contents of wine consist of flavonoids and nonflavonoids and depend on the grape variety, vineyard location, cultivation system, climate, and soil type, vine cultivation practices, harvesting time, production process, and aging. The polyphenolic molecules have a functional role in that they behave as antioxidants against the free radicals and show a physiological role as well; in fact, they increase the antioxidant capacity in the human body after red wine consumption. ${ }^{8}$ Functional ingredients of grape seeds, skins and musts include phenolics such as monomeric flavanols catechin and epicatechin, dimeric, trimeric and polymeric proanthocyanidins, phenolic acids (gallic acid and ellagic acid) and anthocyanins., ${ }^{9,10}$ Polyphenolic antioxidants of grape are very effective in preventing cancer and cardiovascular diseases. ${ }^{11}$ These phenolics were reported to exhibit antioxidant activity in vivo and in vitro in a number of studies ${ }^{12-15}$ and are more effective than vitamin $\mathrm{C}$ and $\mathrm{E}^{7}$ The highest values of antioxidant activity, inhibition of low-density lipoproteins and total polyphenols were determined in pomace, grapes and must. ${ }^{16}$ Grape skins proved to be rich sources of anthocyanins, hydroxycinnamic acids, flavanols and flavonol glycosides, ${ }^{17}$ whereas flavanols are mainly present in seeds ${ }^{18}$ and could exert antibacterial activities. ${ }^{19}$ Katalinić and colleagues ${ }^{20}$ elucidated different reducing/antioxidant power of red and white wines in view of their different phenolic composition. Another important compound contained in wine and grapes is resveratrol, which is a free radical scavenger and inhibits the risk of cardiovascular diseases. ${ }^{21}$ Resveratrol behaves as a powerful antioxidant, both via classical, hydroxyl-radical scavenging and via a novel, glutathione-sparing mechanism. ${ }^{22}$ The French have low coronary heart disease mortality with high fat consumption; this epidemiological anomaly is known as the "French Paradox" and is commonly attributed to the consumption of red wine.$^{5,23}$ Red wine is a complex fluid containing grape, yeast, and wood-derived phenolic compounds, the majority of which have been recognized as potent antioxidants. ${ }^{24}$ Assessment of the antioxidant activity of a serving of $100 \mathrm{~g}$ fresh weight fruit, vegetables and beverage ${ }^{25}$ confirmed very high antioxidant activity of red wine: 1 glass $(150 \mathrm{~mL})$ red wine $=12$ glasses white wine $=2$ cups of tea $=4$ apples $=5$ portions of onion $=5.5$ portions of egg plant $=3.5$ glasses of blackcurrant juice $=3.5(500 \mathrm{~mL})$ glasses of beer $=7$ glasses of orange juice $=20$ glasses of apple juice. Antioxidant capacity of wine on human low-density lipoprotein (LDL) oxidation and antiplatelet properties are related to the content of polyphenols contained in wines, which improve aortic biomechanical properties. Wine may be protective against oxidative stress leading to hypertension, insulin resistance, and type 2 diabetes. ${ }^{26}$ Red wine has a beneficial effect on the modulation of endothelial progenitor cells, which play a significant role in regeneration of damaged blood vessels. ${ }^{27}$ Probit analysis of the antitumorigenic activities of four major red wine polyphenols revealed that quercetin was the most and gallic acid the least effective. ${ }^{28}$ Nevertheless, red wine phenolics can also interact with iron and protein in the lumen during digestion and, consequently, decrease the antioxidant capacity of phenolics. ${ }^{29}$ Likewise, a part of wine polyphenols (35\%-60\% of total polyphenols in red wine and about $9 \%$ in white wine) are associated with dietary fibre, are not bioaccesible in the human small intestine, and reach the colon along with dietary fiber. ${ }^{30}$ Content of polyphenols, composition of phenolic complex and antioxidative or antiradical capacity of wines could be affected by many extrinsic and intrinsic factors, such as variety, wine growing area and climatic conditions, quality of wine, and, not least, technological procedures during wine-making. ${ }^{31}$ Color evolution during vinification and aging has been attributed to the progressive changes of phenolic compounds extracted from grapes. ${ }^{32}$ In recent years, many studies focused on the dynamics of polyphenol extraction during maceration processes of grape varieties. ${ }^{33}$ What is important is the evolution of grape polyphenol oxidase activity and phenolic content during wine maturation and vinification, changes and evolution of polyphenols in young red wines, and changes of the hydrophilic and lipophilic antioxidant activity of white and red wines during the wine-making process. ${ }^{34}$ Some authors put more emphasis on the maceration process, ${ }^{36}$ others on grape maturation, ${ }^{35}$ when quantitative changes in oligomeric phenolics occur. In addition, changes in antioxidant capacity of Tanat red wines during early maturation were reported. ${ }^{36}$ The aging of sparkling wines manufactured from red and white grape varieties $^{37}$ and different copigmentation models by interaction of anthocyanins and catechins play an important role during the aging process of wine. ${ }^{38,39}$ Phenolic content and antioxidant activity could also be affected by storage conditions or a conventional or ecological way of wine production. ${ }^{40}$

\section{Grape and wine antioxidants}

Grapes contain a large number of different phenolic compounds in skins, pulp and seeds that are molecules (especially 
anthocyanins, catechins and oligomeric proanthocyanidins) partially extracted during wine-making. ${ }^{41}$ Catechin oligomers, proanthocyanidin dimers and trimers, along with other monomeric wine phenolics were extracted and then purified from grapes and grape seeds ${ }^{42}$ and tested for their inhibition of LDL oxidation. Among the various phenolic antioxidants present in red wine, (+)-catechin, (-)-epicatechin, proanthocyanidins, anthocyanins, resveratrol, quercetin and its glycoside (rutinoside) rutin (Figures 1,2) are the most potent, ${ }^{43}$ since they have been found to protect human
LDL against oxidation more efficiently than $\alpha$-tocopherol on a molar basis. The anthocyanins in red wine made from blue grapes Vitis vinifera L. include the monoglucosides of delphinidin, petunidin, peonidin, cyanidin, malvidin, their acylated derivatives, pyranoanthocyanins, and polymeric forms. At present, several hundreds of different phenolic compounds from the red wines have been identified. Over twenty major anthocyanins (glycosides of anthocyanidins) contained in red wines were recently refered ${ }^{44}$ of which the main components were 3-O-glucosides of malvidin,

Anthocyanins<smiles>[R6]Oc1cc2c([O-])cc(O)cc2[o+]c1-c1cc([R2])c(O)c([R2])c1</smiles>

$$
\begin{array}{ll}
\mathrm{R}_{1}=\mathrm{OH}, \mathrm{R}_{2}=\mathrm{R}_{4}=\mathrm{H}, \mathrm{R}_{3}=\text { glu } & \text { cyanidin-3-O-glucoside } \\
\mathrm{R}_{1}=\mathrm{R}_{2}=\mathrm{OH}, \mathrm{R}_{4}=\mathrm{H}, \mathrm{R}_{3}=\text { glu } & \text { delphinidin-3-O-glucoside } \\
\mathrm{R}_{1}=\mathrm{OCH} \mathrm{H}_{3}, \mathrm{R}_{2}=\mathrm{R}_{4}=\mathrm{H}, \mathrm{R}_{3}=\text { glu } & \text { peonidin-3-O-glucoside } \\
\mathrm{R}_{1}=\mathrm{OCH} \mathrm{C}_{3}, \mathrm{R}_{2}=\mathrm{OH}, \mathrm{R}_{4}=\mathrm{H}, \mathrm{R}_{3}=\text { glu } & \text { petunidin-3-O-glucoside } \\
\mathrm{R}_{1}=\mathrm{R}_{2}=\mathrm{OCH}_{3}, \mathrm{R}_{4}=\mathrm{H}, \mathrm{R}_{3}=\text { glu } & \text { malvidin-3-O-glucoside }
\end{array}
$$<smiles>Oc1cc(O)c2c(c1)O[C@H](c1ccc(O)c(O)c1)[C@H](O)[C@H]2c1c(O)cc(O)c2c1O[C@H](c1ccc(O)c(O)c1)[C@H](O)C2</smiles>

procyanidin $\mathrm{B} 1$ [epicatechin- $(4 \beta \rightarrow 8)$-catechin] $\underline{\text { Procyanidins }}$<smiles>Oc1cc(O)c2c(c1)O[C@H](c1ccc(O)c(O)c1)[C@H](O)[C@H]2c1c(O)cc(O)c2c1O[C@H](c1ccc(O)c(O)c1)[C@H](O)C2</smiles>

procyanidin $\mathrm{B} 2$

[epicatechin- $(4 \beta \rightarrow 8)$-epicatechin]

Figure I Major anthocyanins contained in red grapes and wine. 


\section{$\underline{\text { Hydroxybenzoic acids }}$}<smiles>[R]COC(=O)c1cc([R])c([R])c([R])c1</smiles>

gallic acid: $\mathrm{R}_{1}=\mathrm{H}, \mathrm{R}_{2}=\mathrm{R}_{3}=\mathrm{R}_{4}=\mathrm{OH}$

protocatechuic acid: $\mathrm{R}_{1}=\mathrm{R}_{4}=\mathrm{H}, \mathrm{R}_{2}=\mathrm{R}_{3}=\mathrm{OH}$

syringic acid: $\mathrm{R}_{1}=\mathrm{H}, \mathrm{R}_{3}=\mathrm{OH}, \mathrm{R}_{2}=\mathrm{R}_{4}=\mathrm{OCH}_{3}$ vanillic acid: $\mathrm{R}_{1}=\mathrm{R}_{4}=\mathrm{H}, \mathrm{R}_{3}=\mathrm{OH}, \mathrm{R}_{2}=\mathrm{OCH}_{3}$ ethyl gallate: $\mathrm{R}_{1}=\mathrm{CH}_{2}-\mathrm{CH}_{3}, \mathrm{R}_{2}=\mathrm{R}_{3}=\mathrm{R}_{4}=\mathrm{OH}$<smiles>OCCc1ccc(O)cc1</smiles>

tyrosol
Hydroxycinnamic acids<smiles>[R]c1cc(/C=C/C(=O)O)cc([R])c1[R]</smiles>

p-coumaric acid: $\mathrm{R}_{1}=\mathrm{R}_{3}=\mathrm{H}, \mathrm{R}_{2}=\mathrm{OH}$

caffeic acid: $\mathrm{R}_{3}=\mathrm{H}, \mathrm{R}_{1}=\mathrm{R}_{2}=\mathrm{OH}$

ferulic acid: $\mathrm{R}_{3}=\mathrm{H}, \mathrm{R}_{2}=\mathrm{OH}, \mathrm{R}_{1}=\mathrm{OCH}_{3}$

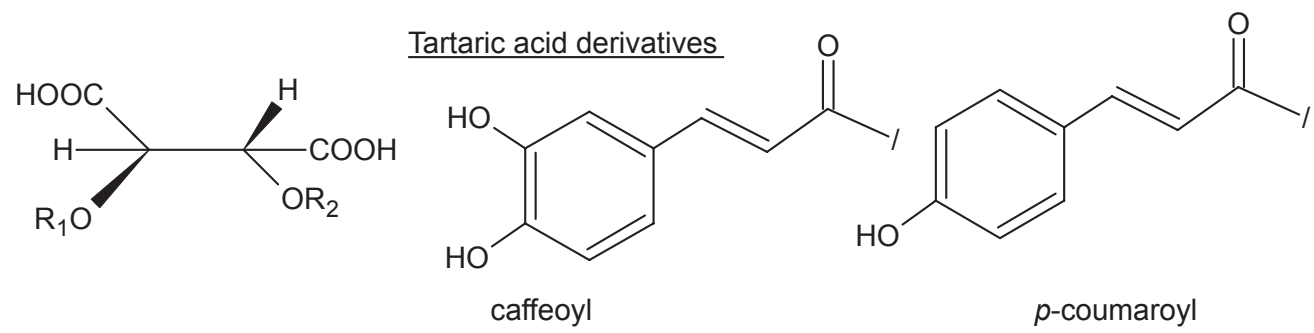

2-O-caffeoyl-(2R,3R)-(+)-tartaric acid: $\mathrm{R}_{1}=$ caffeoyl, $\mathrm{R}_{2}=\mathrm{H}$

2-O-p-coumaroyl-(2R,3R)-(+)-tartaric acid: $\mathrm{R}_{1}=p$-coumaroyl, $\mathrm{R}_{2}=\mathrm{H}$<smiles>Oc1cc(O)c2c(c1)O[C@H](c1ccc(O)c(O)c1)[C@H](O)C2</smiles><smiles>[R]Oc1cc(O)c2c(=O)c(OCC)c(-c3cc([R])c([R])c([R])c3)oc2c1</smiles><smiles>O=c1oc2c(O)c(O)cc3c(=O)oc4c(O)c(O)cc1c4c23</smiles>

ellagic acid
Flavanols<smiles>Oc1ccc([C@@H]2Oc3cc(I)cc(O)c3C[C@H]2O)cc1O</smiles>

Flavonols

kaempferol: $\mathrm{R}_{1}=\mathrm{R}_{2}=\mathrm{R}_{3}=\mathrm{R}_{5}=\mathrm{H}, \mathrm{R}_{4}=\mathrm{OH}$

quercetin: $\mathrm{R}_{1}=\mathrm{R}_{2}=\mathrm{R}_{5}=\mathrm{H}, \mathrm{R}_{3}=\mathrm{R}_{4}=\mathrm{OH}$

myricetin: $\mathrm{R}_{1}=\mathrm{R}_{2}=\mathrm{H}, \mathrm{R}_{3}=\mathrm{R}_{4}=\mathrm{R}_{5}=\mathrm{OH}$

rhamnetin: $\mathrm{R}_{1}=\mathrm{R}_{5}=\mathrm{H}, \mathrm{R}_{3}=\mathrm{R}_{4}=\mathrm{OH}, \mathrm{R}_{2}=\mathrm{CH}_{3}$ isorhamnetin: $\mathrm{R}_{1}=\mathrm{R}_{2}=\mathrm{R}_{5}=\mathrm{H}, \mathrm{R}_{4}=\mathrm{OH}, \mathrm{R}_{3}=\mathrm{OCH}_{3}$ isoquercitrin: $\mathrm{R}_{1}=$ glu, $\mathrm{R}_{2}=\mathrm{R}_{5}=\mathrm{H}, \mathrm{R}_{3}=\mathrm{R}_{4}=\mathrm{OH}$ rutin: $\mathrm{R}_{1}=$ glu-rha, $\mathrm{R}_{2}=\mathrm{R}_{5}=\mathrm{H}, \mathrm{R}_{3}=\mathrm{R}_{4}=\mathrm{OH}$ isorhamnetin-3-O-glucoside: $\mathrm{R}_{1}=$ glu, $\mathrm{R}_{2}=\mathrm{R}_{5}=\mathrm{H}, \mathrm{R}_{3}=\mathrm{OCH}_{3}, \mathrm{R}_{4}=\mathrm{OH}$ kaempferol-3-O-glucoside: $\mathrm{R}_{1}=$ glu, $\mathrm{R}_{2}=\mathrm{R}_{3}=\mathrm{R}_{5}=\mathrm{H}, \mathrm{R}_{4}=\mathrm{OH}$

Figure $\mathbf{2}$ Structure of main phenolic acids and flavanols present in grapes and wines. 
peonidin, petunidin, delphidin and cyanidin found also in Vitis vinifera cell suspension cultures (Figure 1, Table 1). ${ }^{45}$ Coumaroylated-glucoside derivatives of malvidin, petunidin, peonidin, and delphinidin were observed and acetylated glucosides of peonidin, petunidin and malvidin were identified. ${ }^{46}$ Red wines contain carboxypyranomalvidine glucosides - vitisins: vitisin A - 5-carboxypyranomalvidin3-O- $\beta$-D-glucoside ${ }^{47}$ and vitisin $\mathrm{B}$ - pyranomalvidin-3-O$\beta$-D-glucoside (Figure 3). Proanthocyanidins are contained especially in grape seeds. ${ }^{48}$ In Portuguese red wines from Dão

Table I Main grape and wine phenolic antioxidants and their classification

\begin{tabular}{|c|c|}
\hline $\begin{array}{l}\text { Class of wine } \\
\text { antioxidants }\end{array}$ & Compound \\
\hline \multirow[t]{2}{*}{ Flavanols } & (+)-catechin, $90,16,17,18,41,43,53,59,135,138$ \\
\hline & (-)-epicatechin $9,10,16,17,18,41,43,53,59,135,138$ \\
\hline \multirow[t]{6}{*}{ Hydroxybenzoic acids } & gallic acid , $^{90,16,17,49,53,59,138}$ \\
\hline & protocatechuic acid ${ }^{53,59}$ \\
\hline & syringic acid $d^{59,138}$ \\
\hline & vanillic acid ${ }^{59,138}$ \\
\hline & ethyl gallate ${ }^{59}$ \\
\hline & ellagic acid ${ }^{9,10}$ \\
\hline \multirow[t]{4}{*}{ Hydroxycinnamic acids } & p-coumaric acid ${ }^{17,18,49,59135,138}$ \\
\hline & o-coumaric acid ${ }^{138}$ \\
\hline & caffeic acid ${ }^{17,18,49,59,135,138}$ \\
\hline & ferulic acid ${ }^{17,18,59,135}$ \\
\hline \multirow[t]{3}{*}{ Tartaric acid derivatives } & $\begin{array}{l}\text { caftaric acid }(2-O-\text { caffeoyl-(2R,3R)-(+)- } \\
\text { tartraric acid })^{49,50,135}\end{array}$ \\
\hline & $\begin{array}{l}\text { fertaric acid }(2-O-\text { feruloyl-( } 2 R, 3 R)-(+)- \\
\text { tartraric acid })^{50,135}\end{array}$ \\
\hline & $\begin{array}{l}\text { coutaric acid (2-O-p-coumaryl-(2R,3R)- } \\
(+) \text {-tartaric acid })^{49,50,135}\end{array}$ \\
\hline \multirow[t]{2}{*}{ Proanthocyanidins } & procyanidin $\left.B\right|^{9,10,41,42,48,59,107}$ \\
\hline & procyanidin $B 2^{9,10,41,42,48,59,107}$ \\
\hline \multirow[t]{4}{*}{ Phenols } & tyrosol ${ }^{59,120,138}$ \\
\hline & hydroxytyrosol ${ }^{138}$ \\
\hline & 4-ethylguiacol ${ }^{49}$ \\
\hline & tryphtophol ${ }^{120}$ \\
\hline \multirow[t]{9}{*}{ Flavonols } & kaempferol $\left.\right|^{5,59}$ \\
\hline & quercetin ${ }^{43,51,53,59,105}$ \\
\hline & rhamnetin ${ }^{51,59}$ \\
\hline & isorhamnetin $^{51,59}$ \\
\hline & myricetin ${ }^{51,59}$ \\
\hline & kaempferol-3-O glucoside ${ }^{18,51,59}$ \\
\hline & isorhamnetin-3-O-glucoside $18,51,53,59$ \\
\hline & isoquercitrin ${ }^{18,51,53,59,105}$ \\
\hline & rutin $^{18,43,51,59,105}$ \\
\hline
\end{tabular}

(Continued)
Table I (Continued)

\begin{tabular}{|c|c|}
\hline $\begin{array}{l}\text { Class of wine } \\
\text { antioxidants }\end{array}$ & Compound \\
\hline $\begin{array}{l}\text { Anthocyanins } \\
\text { (coumaroylated, acylated, } \\
\text { Pyranoanthocyanins) }\end{array}$ & cyanidin-3-O-glucoside ${ }^{17,41,44,46,51,138}$ \\
\hline & $\begin{array}{l}\text { delphinidin-3-O-glucoside } \mathrm{e}^{17,41,44,46,51,138} \\
\text { peonidin-3-O-glucoside }{ }^{17,41,44,46,51,138} \\
\text { petunidin-3-O-glucoside }{ }^{17,41,44,46,51,138} \\
\text { malvidin-3-O-glucoside }{ }^{17,41,44,46,51,52,138} \\
\text { vitisin } \mathrm{A}^{47} \\
\text { vitisin } \mathrm{B}^{47}\end{array}$ \\
\hline Resveratrols & $\begin{array}{l}\text { cis-resveratrol } \\
\text { trans-9, } 1,103,109 \\
\text { trans-piceid }^{53,59,64,67,109,124} \\
\text { cis-piceid }{ }^{53,59,67,109,124} \\
\text { trans- } \varepsilon \text {-viniferin }^{58} \\
\alpha \text {-viniferin }\end{array}$ \\
\hline
\end{tabular}

region as major anthocyanin malvidin-3-glucoside and from volatile phenols 4-ethylguaiacol was identified. ${ }^{49} \mathrm{By}$ analysis of nonanthocyanin phenolics in red wine it was found $d^{50}$ that phenolic acids predominated over flavonoids with major gallic acid and in lesser amounts present caffeic, $p$-coumaric, trans-caffeoyltartaric and trans-p-coumaroyltartaric acids. In grape seeds monomeric flavanols (catechin and epicatechin), dimeric, trimeric and polymeric proanthocyanidins, and phenolic acids (gallic and ellagic acid) are contained. ${ }^{10}$ The evaluation of young and briefly aged red wines made from single cultivar grapes grown in the warm climate region of La Mancha (Spain) revealed the varietals' differentiation of these wines based on anthocyanin, flavonol and hydroxycinnamic profiles. ${ }^{51}$ Flavonoids, as well as abundant anthocyanins, especially malvidin-3-O-glucoside could contribute to copigmentation. ${ }^{52}$ In Muscatel wines produced in Portugal resveratrol, piceid, gallic acid, protocatechuic acid, catechin, quercetin and quercetin glycosides were determined..$^{53}$

These phenolics were reported to exhibit antioxidant activity in vivo and in vitro in a number of studies ${ }^{12-15}$ and are more effective than vitamin $\mathrm{C}$ and $\mathrm{E} .^{7}$ The highest values of antioxidant activity, inhibition of low-density lipoproteins and total polyphenols were determined in pomace, grapes and must. ${ }^{16}$ Grape skins proved to be rich sources of anthocyanins, ${ }^{17}$ hydroxycinnamic acids, flavan-3-ols (class of reduced flavonoids with 2-phenyl-3,4-dihydro-2H-chromen3-ol skeleton) and flavonol glycosides, whereas flavan-3-ols are mainly present in seeds ${ }^{18}$ and could exert antibacterial activities..$^{19}$ Different reducing/antioxidant power of red and 


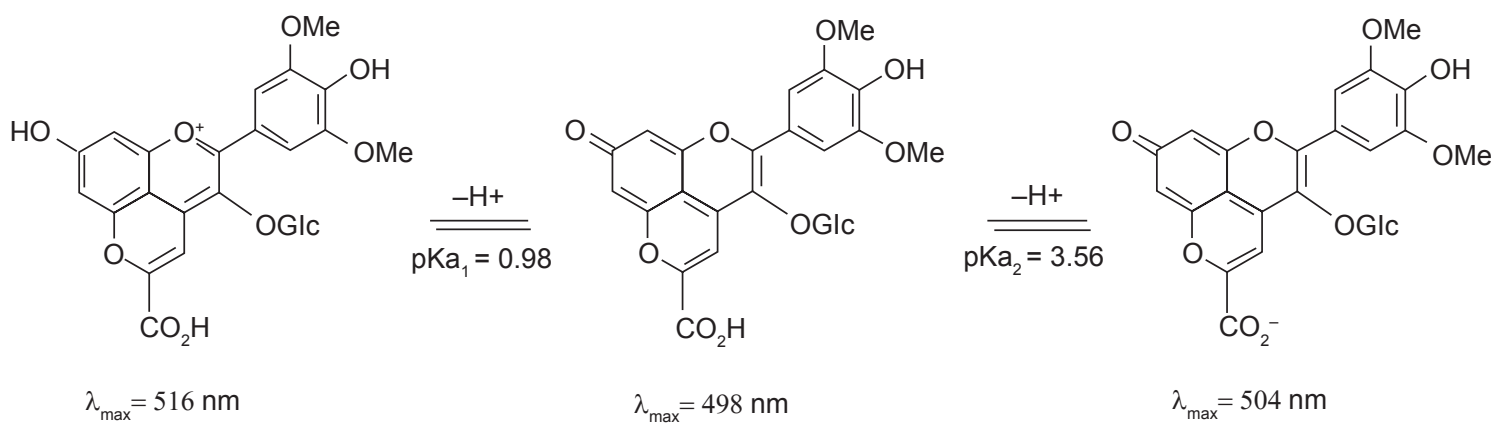

Figure 3 Structure of 5-carboxypyranomalvidin-3-O- $\beta$-D-glucoside. Copyright (C) 1997. Reproduced with permission from Elsevier. Asenstorfer RE, Jones GP. Charge equilibria and $\mathrm{pK}$ values of 5-carboxypyranomalvidin-3-glucoside (vitisin A) by electrophoresis and absorption spectroscopy. Tetrahedron. 1997;63(22):4788-4792.

white wines in view of their different phenolic composition was recently elucidated..$^{20}$

Another important compound contained in wine and grapes is resveratrol (Figure 4), which is a free radical scavenger and inhibits the risk of cardiovascular diseases. ${ }^{21,54}$ Resveratrol is mainly contained in the skins of grapes. ${ }^{55}$ High amounts of trans-resveratrol were found in wines from Bordeaux, Burgundy, Switzerland, and Oregon and, on the contrary, lower amounts are typical of Mediterranean regions. ${ }^{21}$ During an attack of Botrytis cinerea the plant forms a resveratrol barrier. ${ }^{56}$ In recent time, Barger and colleagues ${ }^{57}$ reported that resveratrol in high doses $(4.9 \mathrm{mg} / \mathrm{kg} /$ day $)$, has been shown to extend lifespan in some studies in invertebrates and to prevent early mortality in mice fed a high-fat diet. In grape berries of some varieties piceid, a stilbene glucoside of resveratrol (Figure 5), was also detected, which is related to the biosynthesis of resveratrol and its levels in wine could affect the physiologically available amounts of resveratrol to consumers of wine. Together with resveratrol, its oligomers: dimer trans- $\varepsilon$-viniferin (Figure 6) and trimer $\alpha$-viniferin, also occur
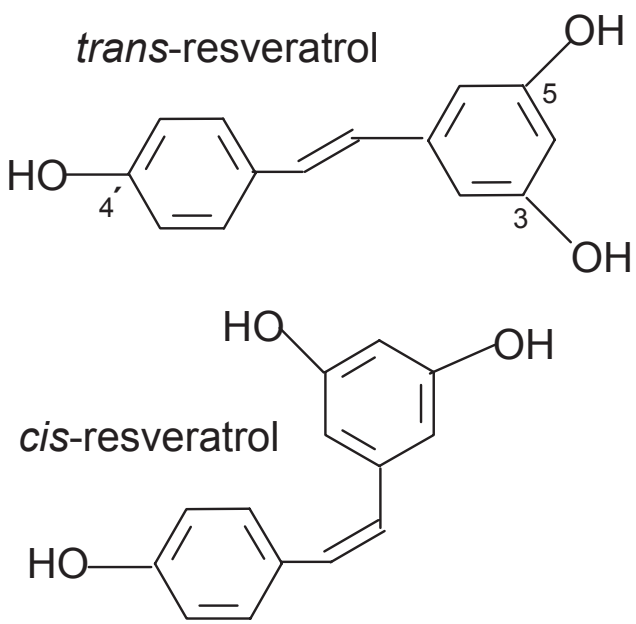

Figure 4 Structures of trans- and cis-resveratrol. in wines. ${ }^{58}$ Two years ago twenty four phenolic compounds were identified in Sicilian red wines (their structures and classification are described in Figures 1-5 and Table 1). ${ }^{59}$

Recently it was found that concentrations of gallic acid, monomeric catechin, and epicatechin were lower in the winery by-product grape skins than in the seeds. ${ }^{16}$ Grape seeds contained the highest quantities of proanthocyanidins (condensed tannins). ${ }^{48}$ Especially dimeric, trimeric, oligomeric, or polymeric proanthocyanidins account for most of the superior antioxidant capacity of grape seeds. ${ }^{9}{ }^{10}$ However, grape skins could be rich sources of anthocyanins, hydroxycinnamic acids, flavanols, and flavonol glycosides. ${ }^{18}$ Contrary to TP the highest trans-resveratrol content (RES) was found in the grape skins and its levels were higher in comparison with the seeds apparently due to relation with the Botrytis infestation. ${ }^{54}$ Free trans-resvetratrol in the musts was contained mainly below the detectable limit. In agreement with Nikfardjam and colleagues, ${ }^{60}$ results of Šulc and colleagues ${ }^{61}$ show that RES is mainly dependent on variety and vintage year. As expected, significant varietal differences and differences between the blue and white grape varieties were confirmed. All average $\mathrm{TP}$ contents were higher in the blue varieties $(282.7 \mathrm{mg} / \mathrm{g}$ DM in grape skins, $546.3 \mathrm{mg} / \mathrm{g} \mathrm{DM}$ in seeds and $326.7 \mathrm{mg} / \mathrm{L}$ in must) when compared with the white varieties $(149.6 \mathrm{mg} / \mathrm{g}$ $\mathrm{DM}$ in skins, $531.2 \mathrm{mg} / \mathrm{g} \mathrm{DM}$ in seeds and $242.9 \mathrm{mg} / \mathrm{L}$ in must). These results are in full accordance with the results of Peña-Neira and colleagues ${ }^{62}$ and Cantos and colleagues. ${ }^{63}$ The highest TP contents were found in the blue Zweigeltrebe, higher TP contents were found in the blue grape varieties Alibernet and St. Laurent. On the contrary, lower TP contents were found in the white grape varieties.

\section{Increasing of trans-resveratrol and phenolics in wines}

Use of $\beta$-glucosidase (EC 3.2.1.21) from different sources increased the trans-resveratrol in some Sicilian wines 


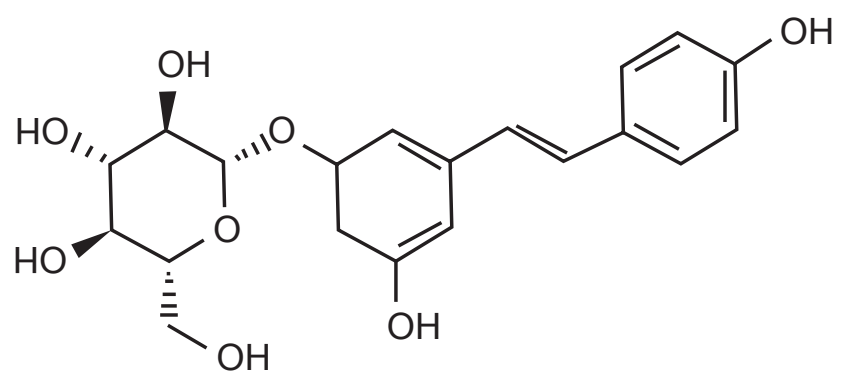

Figure 5 Structure of piceid - resveratrol 3-O- $\beta$-D-glucopyranoside.

by hydrolyzing resveratrol glucoside piceid. ${ }^{64}$ The methyl jasmonate/sucrose treatment was effective in stimulating phenylalanine ammonia lyase, chalcone synthase, stilbene synthase, UDP glucose:flavonoid-O-glucosyltransferase, proteinase inhibitor and chitinase gene expression, and triggered accumulation of both piceids and anthocyanins in cells, and trans-resveratrol and piceids in the extracellular medium. ${ }^{65}$ Hence, methyl jasmonate treatment might be an efficient natural strategy to both protect grapevine berries in the vineyard and increase trans-resveratrol content in grapes and wines. Analogically Nikfardjam and colleagues ${ }^{66}$ investigated trans-resveratrol content in quality Hungarian and German wines from botrytized grapes and determined these values as very high, which is particularly true for the Tokay wines. Another approach is use of an organic way of cultivation. ${ }^{67}$ Organic grape juices showed statistically different $(\mathrm{p}<0.05)$ higher values of total polyphenols and resveratrol as compared conventional grape juices. Purple juices presented higher total polyphenol content and in vitro antioxidant activity as compared to white juices, and this activity was positively correlated with total polyphenol content. Fuhrman and colleagues ${ }^{68}$ have been looking for a way of making white wine with higher polyphenol levels. Whole, crushed grapes were stored for different lengths of time before removing the skins, and they tried adding various concentrations of ethanol to see if that aided polyphenol extraction. Leaving the skins
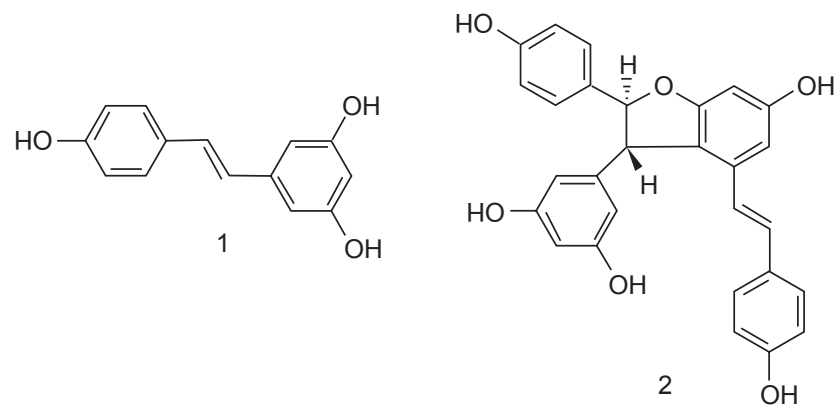

Figure 6 Structures of trans-resveratrol (I) and its dimer trans- $\varepsilon$-viniferin (2) in wine. with the juice for two to 18 hours gave a gradual increase in the white wine's polyphenol content, though it was still 10 times less than red. Adding alcohol gave $60 \%$ higher polyphenol levels, in a dessert wine with a final alcohol content of $18 \%$ and high sugar content. Its antioxidant capacity was directly proportional to its polyphenol content. It was concluded that processing white wine by imposing a short period of grape skin contact in the presence of alcohol leads to extraction of grape skin polyphenols and produces polyphenol-rich white wine with antioxidant characteristics similar to those of red wine. Another approach is to enhance procyanidin oligomers in Tannat red wine. In young wines, procyanidins are found mainly in dimeric and trimeric form and in aged wines the relative degree of polymerization increases to $8-10$. There is an interest in developing grape varieties with high anthocyanin levels with antioxidative and antiproliferative properties through traditional breeding of selected high-polyphenol grape lines. ${ }^{46}$ Talcott and colleagues ${ }^{69}$ evaluated changes in maximum absorbance, total soluble phenolics, isoflavonoids, and anthocyanins in muscadine juice and wine following the addition of isoflavonoid extracts from red clover with maximum color enhancement found at an anthocyanin to cofactor ratio of 1:8. Thus, red clover isoflavonoids proved to be novel and effective color-enhancing compounds when used in low concentrations in young muscadine wines.

\section{Relationship between antioxidant activity, polyphenolic antioxidants, and resveratrol in grape musts, skins, and seeds}

Šulc and colleagues ${ }^{18}$ analyzed 25 samples of grape must, skins, and seeds (Table 2). The average determined TP content was the highest in seeds $(536.6 \mathrm{mg} / \mathrm{g} \mathrm{DM})$; lesser concentrations were found in must $(273.1 \mathrm{mg} / \mathrm{L})$ and skins (165.9 mg/g DM). Seeds contained 3.2 times more TP than grape skins.

AA was measured in grape skins and seeds employing DPPH assay. It follows from the results that AA expressed in ascorbic acid equivalents (AAE, $\mathrm{mg} / \mathrm{mL}$ ) was higher in grape skins of the white grape varieties ( $0.3 \mathrm{AAE})$ in comparison with the blue grape varieties (0.2 AAE), while in seeds the results were reciprocal (1.0 AAE in the blue grape varieties and $0.8 \mathrm{AAE}$ in the white grape varieties). Total flavanols contributed to hydroxyl free radical scavenging efficacy and to a lesser extent to antiradical and reducing ability, ${ }^{70}$ whereas there was a less significant relationship between the antioxidant properties and the total phenolics and only a weak 


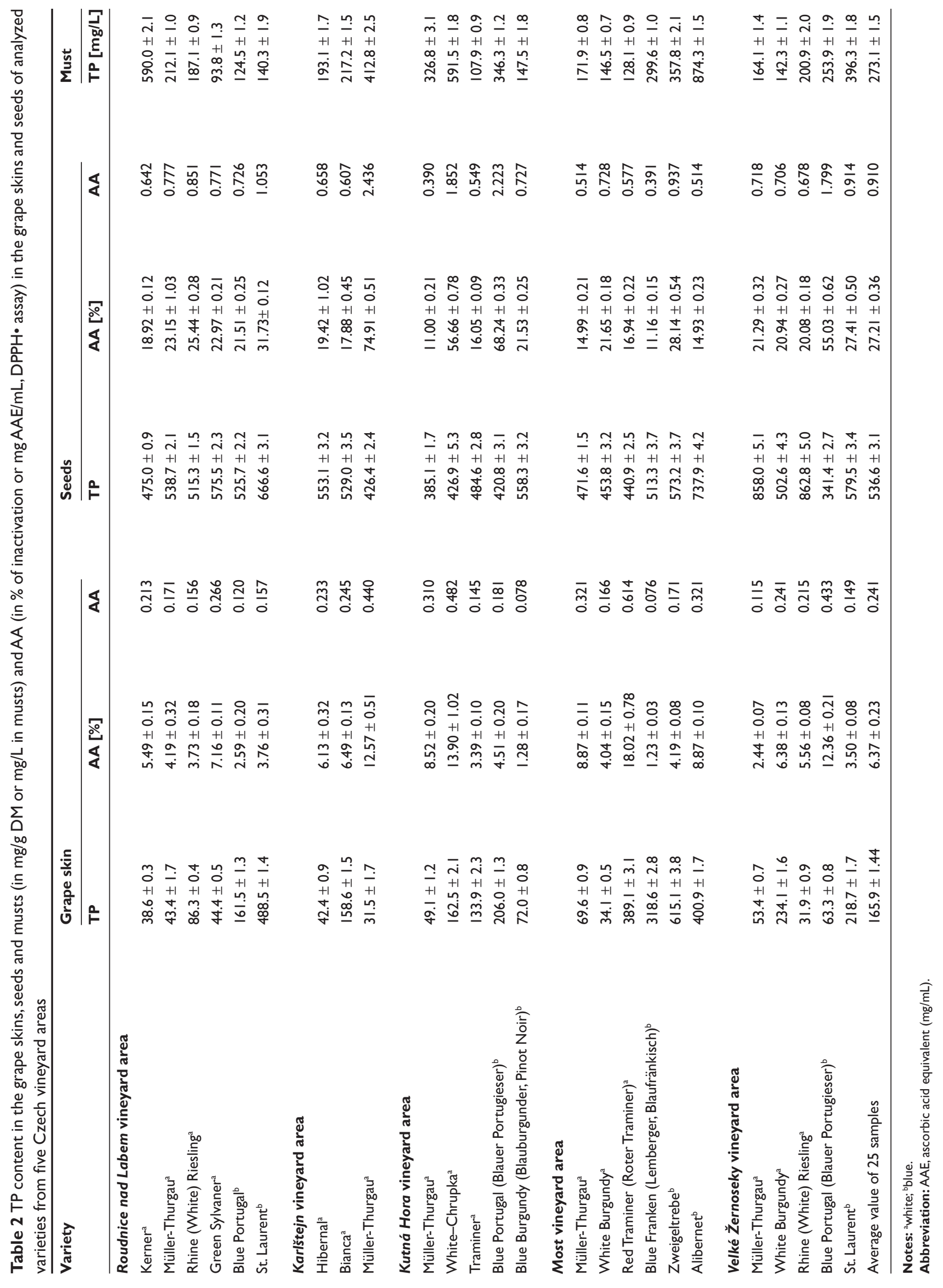


relationship to total anthocyanin content. Kallithraka and colleagues ${ }^{71}$ also revealed a low and statistically insignificant correlation between antiradical activity determined by DPPH assay and total anthocyanin content. Thus, AA estimated using the dipyridyl method, will be dependent on special phenolics content, especially in seeds. Red wine, white wine, and grape juices were characterized by strong antioxidant potential in a similar way. ${ }^{72}$ Also grape juice and wine vinegar were confirmed as good dietary sources of antioxidants. ${ }^{73}$

Condensed tannins (oligomeric and polymeric polyphenols) are considered superior antioxidants as their eventual oxidation may lead to oligomerization via phenol coupling and enlargement of the number of reactive sites. ${ }^{74}$ In addition, gallic acid, monomeric catechin, and epicatechin - three major phenol constituents of grape seeds - contribute to antioxidant capacity in a greater deal. Thus, functional ingredients of grape seeds - monomeric flavanols (catechin and epicatechin), dimeric, trimeric and polymeric proanthocyanidins, and phenol acids (gallic acid and ellagic acid) seem to be major contributors to antioxidant and antiradical activity.., 10 In addition, resveratrol has stronger ability to inhibit lipid peroxidation as compared with other antioxidants. ${ }^{75}$ De Beer and colleagues, ${ }^{76}$ analyzing 139 Pinotage wines, suggested that synergy between phenol compounds does play a role in the wine TAC (16\%-23\% synergic antioxidant activity).

Antioxidant and vasodilatation activity is correlated with the total phenol content and is especially associated with the content of gallic acid, resveratrol and catechin. ${ }^{77}$ Total antioxidant activities of foods (determined against $\mathrm{DPPH}^{\circ}$ ) are well correlated with total phenols $\left(r^{2}=0.95\right) .^{7,12,15}$ Also the assessment of the in vitro antiradical activity employing the stable radical DPPH' showed that there is a significant correlation with total polyphenol content $\left(\mathrm{r}^{2}=0.6499, \mathrm{p}<0.01\right)$, but the most effective was shown to be procyanidin in grape seed extracts $\left(r^{2}=0.7934, p<0.002\right) .{ }^{78}$ A relatively high correlation in red wine between oxygen radical absorbance capacity and malvidin glucosides $\left(\mathrm{r}^{2}=0.75, \mathrm{p}<0.10\right)$, and proanthocyanidins $\left(\mathrm{r}^{2}=0.87, \mathrm{p}<0.05\right)$ and white wines trimeric proanthocynidin fraction $\left(\mathrm{r}^{2}=0.86, \mathrm{p}<0.10\right)$ was found. ${ }^{79,80}$ In contrast to these studies Zafrilla and colleagues ${ }^{40}$ did not find a significant relationship between the total concentrations of phenol compounds in conventional and ecological red and white wines and the antioxidant activity determined by DPPH assay ( $\mathrm{p}<0.05$ ).

Moderate consumption of red wine has been associated with lowering the risk of developing coronary heart disease. ${ }^{81}$ A close relationship between total phenolic content and total antioxidant potential for wines, especially red wines in vitro was found recently. ${ }^{82,83}$ Wine polyphenols could reinforce the endogenous antioxidant system and thereby diminish oxidative damage. ${ }^{84}$ Anthocyanidins also inhibit malignant cell survival. ${ }^{85}$ Studies in long-term models to understand the relationship between the bioavailability of polyphenols and their biological effects are still lacking. Šulc and colleagues ${ }^{86}$ assayed to prove the hypothesis that the AA of red wine from the Czech Republic (Blue Burgundy) is positively correlated with the AA of blood plasma in rats in vivo, after long-term wine consumption (Figure 7). Red wine increased antioxidant activity of blood plasma by approx. $6 \%-12 \%$. At $p=0.05$ statistically significant differences between the control and application groups were found. Both, red wine polyphenols and induction of plasma urate elevation could contribute to increase of plasma antioxidant capacity and thus involve two separate mechanisms in elevation of AA plasma values. ${ }^{86,87}$

\section{Factors influencing levels of major antioxidants and antioxidant activity in grapes and wines Effect of grape/vine varieties and cultivars} Grape must contains relatively high content of total polyphenols (Table 3). Among analyzed blue grape varieties, the highest amount was determined in cv. Royal (427 mg/L); lesser contents were found for Blue Burgundy $(231 \mathrm{mg} / \mathrm{L})$ and St. Laurent (236 mg/L). Significantly lesser contents were found in white varieties: the highest content is characteristic for Muscat Ottonel (267 mg/L), the lowest one in Bacchus $(116 \mathrm{mg} / \mathrm{L})$ and Early Red Veltliner $(160 \mathrm{mg} / \mathrm{L}) .{ }^{88}$

From the evaluation of the phenol potential of Tannat, Cabernet-Sauvignon, and Merlot grapes ${ }^{89}$ and its correspondence with the color and composition of the respective wines resulted that Tannat grapes presented anthocyanin and total polyphenols contents significantly higher. In sixteen red grape cultivars stronger correlation between antioxidant activity and total polyphenol content than antioxidant activity and total anthocyanins was determined ${ }^{90}$.

Frémont ${ }^{54}$ found trans-resveratrol in red wines in concentrations that generally ranged between 0.1 and $15 \mathrm{mg} / \mathrm{L}$. The concentrations of trans-resveratrol in the Czech red wines from different vineyard regions ${ }^{91}$ ranged between $1.035 \mathrm{mg} / \mathrm{L}$ (St. Laurent, Mostecká vineyard region, 1998) to $6.253 \mathrm{mg} / \mathrm{L}$ (Pinot Noir, Roudnická vineyard, 1998), and cis-resveratrol between $0.683 \mathrm{mg} / \mathrm{L}$ (Blaufrankisch, Mutĕnická vineyard, 1986) and $2.806 \mathrm{mg} / \mathrm{L}$ (Pinot Noir, Roudnická vineyard, 1998). Wine samples from Turkey contained higher phenolics and trans-resveratrol levels than the corresponding musts. ${ }^{92}$ 


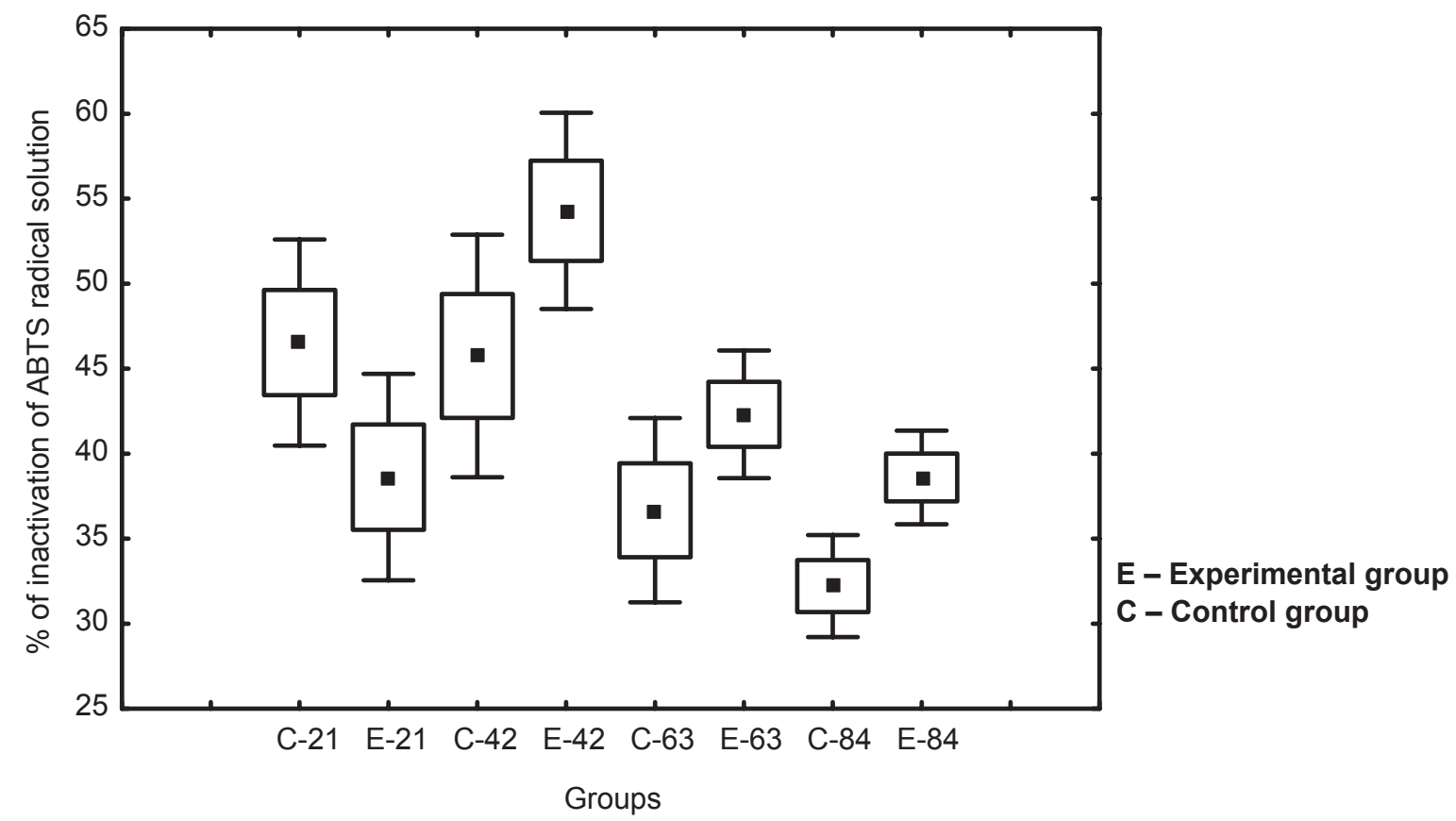

Figure 7 Box diagram of antioxidant activity of blood plasma in rats after long-term red wine consumption.

Significantly higher amounts of total phenols, flavonoids, and antioxidant activities in red wines compared to white wines were demonstrated elsewhere, eg, in selected wines produced in the northeast of Thailand $\mathrm{d}^{93}$ or in white, rosé, and red commercial Terras Madeirenses Portuguese wines from Madeira Island. ${ }^{94}$

From the statistical variance analysis, significant differences $(\mathrm{p}<0.05)$ were found between vintages for total polyphenols. ${ }^{88}$
Also between total polyphenol content in grape skins and seeds and between variety and the part of the plant significant differences were proved. For the trans-resveratrol content vintages were significantly different: skins and seeds and vintage and the part of the plant. In trans-resveratrol content in the skins and the seeds, no statistical differences among varieties were found. All analyzed varieties were cultivated under the same

Table 3 Content of total polyphenols in grape must, skins, and seeds

\begin{tabular}{|c|c|c|c|c|c|c|c|}
\hline \multirow[t]{2}{*}{ White varieties } & \multicolumn{2}{|c|}{ Grape must [g/L] } & \multicolumn{3}{|c|}{ Grape skins [g/kg DM] } & \multicolumn{2}{|c|}{ Grape seeds [g/kg DM] } \\
\hline & 2001 & 2002 & 2001 & 2002 & Average & 2001 & 2002 \\
\hline Aurelius & 0.174 & 0.302 & 3.19 & 10.16 & 6.675 & 90.49 & 133.9 \\
\hline Bacchus & 0.116 & nd & 4.14 & nd & 4.140 & 75.56 & nd \\
\hline Kerner & 0.116 & 0.390 & 2.98 & 8.98 & 5.980 & 67.40 & 78.4 \\
\hline Muscat Ottonel & 0.268 & 0.266 & 6.98 & 13.90 & 10.440 & 85.04 & 102.2 \\
\hline Welschriesling & 0.344 & 0.132 & 6.40 & 11.90 & 9.150 & 76.99 & 78.9 \\
\hline Green Sylvaner & 0.059 & 0.338 & 7.74 & 7.80 & 7.770 & 98.71 & 105.8 \\
\hline Green Veltliner & 0.232 & 0.104 & 10.20 & 10.78 & 10.490 & 94.88 & $1 \mid 4.0$ \\
\hline Early Red Veltliner & 0.074 & 0.245 & 3.57 & 7.47 & 5.520 & 86.95 & 103.9 \\
\hline \multirow[t]{2}{*}{ Blue varieties } & \multicolumn{2}{|c|}{ Grape must [g/L] } & \multicolumn{3}{|c|}{ Grape skins [g/kg DM] } & \multicolumn{2}{|c|}{ Grape seeds [g/kg DM] } \\
\hline & 2001 & 2002 & 2001 & 2002 & Average & 2001 & 2002 \\
\hline Royal & 0.267 & 0.587 & 14.30 & 24.09 & 19.20 & 98.8 & 129.6 \\
\hline Blue Burgundy & 0.114 & 0.348 & 8.57 & 20.42 & 14.50 & 124.1 & 116.8 \\
\hline St. Laurent & 0.086 & 0.385 & 10.52 & 25.25 & 17.89 & 107.9 & 106.7 \\
\hline Zweigeltrebe & 0.196 & 0.468 & 11.02 & 30.87 & 20.95 & 90.6 & 111.8 \\
\hline
\end{tabular}

Note: nd, nondetermined in the year 2002 due to grape bunch atrophy. 
conditions of microclimate, soil and cultivation procedures. The blue vine varieties contained higher amounts of polyphenolic compounds in comparison with the white varieties due to enhanced biosynthesis of colorants and condensed tannins, which is in good correlation with the previous reports. ${ }^{14,17,63,95}$ The total polyphenol concentration is principally correlated with the antioxidant potency and the antiradical activity ${ }^{96}$ and a good correlation between the total polyphenol content and their antioxidant power was confirmed. ${ }^{13}$

Obtained results also proved the effect of vintage. In the year 2001 lower TP levels were estimated in comparison with the year 2002. It could be correlated with an extraordinarily warm year in $2002\left(\Delta \mathrm{t}=+1.7^{\circ} \mathrm{C}\right)$ in comparison with the year 2001 $\left(\Delta \mathrm{t}=+0.9^{\circ} \mathrm{C}\right)$. Both years could be evaluated as humid. Total polyphenol concentrations in berry skin were higher in sunexposed grapes. ${ }^{97}$ Likewise, increased vine water deficit causes small increases in anthocyanins and decreases in flavonols. ${ }^{98}$

The effect of an attack with Botrytis cinerea as a biotic stress factor $^{99}$ influenced apparently higher content in the year 2001. Lesser content in the skins in comparison with the seeds could be caused by its metabolization ${ }^{100}$ and by the fact that only free trans-resveratrol was determined. Higher levels of trans-resveratrol were found in blue varieties as compared with white ones, ${ }^{11}$ because resveratrol is more sensitive to oxidation in white musts. ${ }^{101}$ Statistically significant differences were found between some varieties, especially Blue Burgundy x Bacchus, Royal, Kerner, Welschriesling and Kerner x Royal, St. Laurent, Zweigeltrebe and Royal x Welschriesling. Very low levels of trans-resveratrol in musts could be correlated with the activity of isoenzyme $\mathrm{B}_{5}$, whose activity is the highest at $\mathrm{pH} 3.0-4.0 .^{102}$ Abril and colleagues ${ }^{103}$ evaluated concentrations of trans- and cis-resveratrol isomers of 98 commercial wines of the four designations of origin, from several vintages, and found concentration of trans-resveratrol ranging from 0.32 to $4.44 \mathrm{mg} / \mathrm{L}$ in red wines and from 0.12 to $2.80 \mathrm{mg} / \mathrm{L}$ in rosé wines. An improved method for resveratrol determination in 29 red Greek wines of appellation of origin was applied; ${ }^{104}$ the concentrations found varied between 0.550 and $2.534 \mathrm{mg} / \mathrm{L}$ with the highest concentration for the grape variety Mandilaria.

\section{Effect of growing locations (altitude, soil) and climatic conditions (temperature, sum of precipitation, vintage years) on major grape and wine antioxidants and antioxidant activity}

Faitová and colleagues, ${ }^{31}$ using the spectrophotometric method in white Riesling from different vineyard subregions, kinds of wine, and vintages, determined the content of total polyphenols (TP) and that of trans-resveratrol (RES) by the HPLC method (Tables 4-6). The TP content was presented as gallic acid equivalent per liter of wine, and the RES content as trans-resveratrol per liter of wine. TP values in the vineyard region of Bohemia ranged from 223.0 to $532.7 \mathrm{mg} / \mathrm{L}$ (average content $330.3 \mathrm{mg} / \mathrm{L}$ ), and were higher than in the vineyard region of Moravia from 175.0 to $465.0 \mathrm{mg} / \mathrm{L}$ (average content $271.7 \mathrm{mg} / \mathrm{L}$ ). RES values in the vineyard region of Bohemia ranged from $<0.033$ to $0.421 \mathrm{mg} / \mathrm{L}$ (average content $0.117 \mathrm{mg} / \mathrm{L}$ ), in the vineyard region of Moravia from $<0.033$ to $0.875 \mathrm{mg} / \mathrm{L}$ (average content $0.123 \mathrm{mg} / \mathrm{L}$ ). The harvest year of 1994 was evaluated as that providing the highest average levels of TP $(386.5 \mathrm{mg} / \mathrm{L})$ and RES $(0.201 \mathrm{mg} / \mathrm{L})$. The kind of wine with the highest average TP was the kind of "selected grapes" (327.2 mg/L), while the highest average RES content was found in the late harvest wine $(0.141 \mathrm{mg} / \mathrm{L})$. Increased concentrations of free and conjugated quercetin in Moravian red wines in 2000 were found, which could be a consequence of a longer sunshine period in that year. ${ }^{105}$

Statistical analysis of variance ${ }^{61}$ (Table 4) revealed statistically significant differences among vineyard regions and varieties in total polyphenol content in grape skins $(\mathrm{p}<0.05)$. Multivariate analysis applied to the phenol compounds revealed both qualitative and quantitative differences in polyphenolic antioxidants of red and white Spanish wines of different geographical origin. ${ }^{62}$ Kallithraka and colleagues ${ }^{106}$ suggested some of the unexploited rare native Greek varieties contained appreciable amounts of noncolored phenols as well as anthocyanins as worthy of use for the production of quality wines. Furthermore, the antioxidant efficiency of red wines tested appears to be largely influenced by the proanthocyanidin level, with anthocyanins playing a minor role. ${ }^{107}$ Kallithraka and colleagues ${ }^{104}$ determined that the red wines produced by grape varieties grown in the Greek islands were richer in trans-resveratrol. The results obtained by Sakkiadi and colleagues ${ }^{43}$ reflect previous reports on other southern European wines and support the conclusion that relatively low trans-resveratrol concentrations are present in Mediterranean wines. Californian wines made from Cabernet Sauvignon were also lower than the Greek wines in trans-resveratrol level $0.46-0.74 \mathrm{mg} / \mathrm{L}, 0.002 \mathrm{mg} / \mathrm{L}$; 0.05 to $0.09 \mathrm{mg} / \mathrm{L}$. However Californian wines made from blended varieties showed a higher trans-resveratrol content (2.74-5.77 mg/L). The richest California variety was Pinot Noir containing from 3.72 to $7.99 \mathrm{mg} / \mathrm{L}$ trans-resveratrol. Portuguese red wines had a similar trans-resveratrol content 
Table 4 Content of total polyphenols (TP) and resveratrol (RES) in white Riesling related to the vineyard sub-regions (the first part of table is the vineyard region of Moravia and the second part of the table is the vineyard region of Bohemia)

\begin{tabular}{|c|c|c|c|c|c|}
\hline Vineyard sub-regions & Frequency & $\begin{array}{l}\text { Average TP } \\
\text { content }[\mathrm{mg} / \mathrm{L}]\end{array}$ & $\begin{array}{l}\text { Range of TP } \\
\text { content }[\mathrm{mg} / \mathrm{L}]\end{array}$ & $\begin{array}{l}\text { Average RES } \\
\text { content }[\mathrm{mg} / \mathrm{L}]\end{array}$ & $\begin{array}{l}\text { Range of RES } \\
\text { content }[\mathrm{mg} / \mathrm{L}]\end{array}$ \\
\hline Brněnská & 1 & - & 265.0 & - & 0.045 \\
\hline Bzenecká & 3 & 264.62 & $261.1-269.5$ & 0.086 & $<0.033-0.169$ \\
\hline Kyjovská & I & - & 243.4 & - & 0.004 \\
\hline Mikulovská & 13 & 258.5 & $|75.0-37| .8$ & 0.144 & $<0.033-0.875$ \\
\hline Mutěnická & 9 & 238.7 & $171.7-288.3$ & 0.132 & $<0.033-0.447$ \\
\hline Podluží & 3 & 266.0 & $226.3-328.1$ & 0.063 & $0.044-0.095$ \\
\hline Strážnická & 3 & 277.1 & $241.7-315.5$ & 0.113 & $0.077-0.161$ \\
\hline Uherskohradišs'ská & 1 & - & 280.6 & - & 0.072 \\
\hline Velkopavlovická & 6 & 298.9 & $212.1-465.0$ & 0.145 & $0.038-0.185$ \\
\hline Znojemská & 12 & 263.1 & $|7| .7-358.0$ & 0.149 & $<0.033-0.466$ \\
\hline Mělnická & 7 & 305.1 & $223.0-443.8$ & 0.092 & $<0.033-0.145$ \\
\hline Mostecká & I & - & 353.5 & - & - \\
\hline Pražská & I & - & 378.4 & - & 0.185 \\
\hline Roudnická & 4 & 370.1 & $282.6-532.7$ & 0.262 & $0.050-0.421$ \\
\hline Žernosecká & 6 & 321.3 & $245.0-392.0$ & 0.051 & $<0.033-0.070$ \\
\hline Vineyard region of Bohemia & 19 & 330.3 & $223.0-532.7$ & 0.115 & $<0.033-0.421$ \\
\hline Vineyard region of Moravia & 57 & 271.7 & $175.0-465.0$ & 0.121 & $<0.033-0.875$ \\
\hline
\end{tabular}

Note: $<0.033$, below range of detection.

to the Greek wines (average values $1.0 \mathrm{mg} / \mathrm{L}$ for monovarietal and $1.5 \mathrm{mg} / \mathrm{l}$ for blended wines, whereas French $(3 \mathrm{mg} / \mathrm{L})$ and Spanish wines $(5.13 \mathrm{mg} / \mathrm{L}$ from Pinot Noir grape varieties, $3.99 \mathrm{mg} / \mathrm{L}$ from Merlot and $2.43 \mathrm{mg} / \mathrm{L}$ from Grenache) were higher in trans-resveratrol level. However, Spanish wines made from Cabernet Sauvignon $(1.42 \mathrm{mg} / \mathrm{L})$ and Tempranillo $(1.33 \mathrm{mg} / \mathrm{L})$ grape varieties had similar trans-resveratrol content to the Greek wines. For Italian wines, it ranged between 0.5 and $10 \mathrm{mg} / \mathrm{L}$ depending on cultivar, area of cultivation, climate and winemaking technology. Wines from relatively warm and dry climatic conditions tended towards lesser resveratrol levels. The highest trans-resveratrol levels was found in the wines made from Pinot Noir and St. Laurent; the average levels of trans-resveratrol in red wine varied greatly from one region to another, but no specific region was significantly different from all the others. ${ }^{108}$ Intense UV irradiation leads to complete disappearance of trans- and cis-isomers of piceid and to a large decrease in resveratrol isomers content. ${ }^{109}$

\section{Effect of winemaking process and effect of storage conditions and wine age}

Phenol levels in wine and grape juice are affected by numerous processing conditions (crushing, pressing, sulphite addition, skin contact, oak aging). Lachman and colleagues ${ }^{110}$ measured TAS values during the winemaking process with

Table 5 Total polyphenol (TP) content and resveratrol (RES) content in white Riesling related to the type of wine

\begin{tabular}{llllll}
\hline Type of wine & Frequency & $\begin{array}{l}\text { Range of TP } \\
\text { content [mg/L] }\end{array}$ & $\begin{array}{l}\text { Average of TP } \\
\text { content [mg/L] }\end{array}$ & $\begin{array}{l}\text { Range of RES } \\
\text { content [mg/L] }\end{array}$ & $\begin{array}{l}\text { Average of RES } \\
\text { content [mg/L] }\end{array}$ \\
\hline Quality wine & 27 & $197.7-465.0$ & 272.4 & $<0.033-0.466$ & 0.123 \\
Late harvest & 29 & $175.0-362.1$ & 264.7 & $<0.033-0.875$ & 0.128 \\
Archive & 7 & $243.4-532.7$ & 321.6 & $0.044-0.421$ & 0.141 \\
Cabinet wine & 11 & $193.6-443.8$ & 300.3 & $<0.033-0.242$ & 0.102 \\
Selected grapes & 2 & $282.6-371.8$ & 327.2 & $0.050-0.090$ & 0.070 \\
Average & 76 & $175.0-532.7$ & 279.5 & $<0.033-0.875$ & 0.122 \\
\hline
\end{tabular}

Note: $<0.033$, below range of detection. 
Table 6 Total polyphenol (TP) content and resveratrol (RES) content in white Riesling related to vintage years

\begin{tabular}{llllll}
\hline Vintage & Frequency & $\begin{array}{l}\text { Range of TP } \\
\text { content [mg/L] }\end{array}$ & $\begin{array}{l}\text { Average TP } \\
\text { content [mg/L] }\end{array}$ & $\begin{array}{l}\text { Range of RES } \\
\text { content [mg/L] }\end{array}$ & $\begin{array}{l}\text { Average RES } \\
\text { content [mg/L] }\end{array}$ \\
\hline 2002 & 7 & $171.7-394.5$ & 267.1 & $<0.033-0.144$ & 0.076 \\
2001 & 16 & $175.0-465.0$ & 267.2 & $<0.033-0.242$ & 0.096 \\
2000 & 23 & $171.7-443.8$ & 293.7 & $<0.033-0.875$ & 0.135 \\
1999 & 14 & $215.3-334.8$ & 260.3 & $<0.033-0.358$ & 0.125 \\
1998 & 6 & $188.8-370.2$ & 281.3 & $0.057-0.218$ & 0.156 \\
1997 & 1 & 255.1 & - & 0.123 & - \\
1996 & 1 & 201.2 & - & 0.075 & - \\
1994 & 3 & $235.2-532.7$ & 386.5 & $0.070-0.421$ & 0.162 \\
1990 & 1 & 243.4 & - & 0.136 & - \\
1989 & 1 & 279.0 & - & 0.057 & - \\
1985 & 1 & 349.0 & - & $<0.033-0.875$ & - \\
Average & 76 & $175.0-532.7$ & 279.5 & & 0.122 \\
\hline
\end{tabular}

Note: $<0.033$, below range of detection.

the DPPH assay and the ABTS assay (Figure 8). The TAS of white wines was significantly lesser in comparison with the red wines (Figures 9, 10). White wines showed a median value of approximately $0.2 \mathrm{AAE}$ as compared to the red wines (2.2 AAE) and had ten times as much TAS when determined by DPPH assay. In the ABTS assay, the AAE values were higher; the TAS increase was 3.7 times higher in the red wines in comparison with the white wines. The difference between the white wine varieties determined by both methods was nearly the same. The TAS values were strongly affected during the winemaking process. The highest values were determined in the St. Laurent variety with a high increase by week 4 (15.0 AAE by ABTS assay) and between weeks 6 and 7 (3.4 AAE by DPPH). A significant difference was found between the blue and white varieties. The TAS found by ABTS and DPPH assays in the white and blue vine varieties differed significantly, which is well in accordance with the recent data ${ }^{111}$ suggesting a high polyphenol content in blue vine varieties. Statistically significant differences were also found between individual blue vine varieties, contrary to white varieties.

The winemaking process strongly affected the TAS and it is evidently in close relation to the content of polyphenols ${ }^{12}$ (TAS has been determined by different methods: ABTS, DPPH and ORAC (oxygen radical absorbance capacity). In red wines produced from blue vine varieties, mostly the anthocyanin content is affected by different vinification methods. ${ }^{113}$ According to our previous results, the stage of

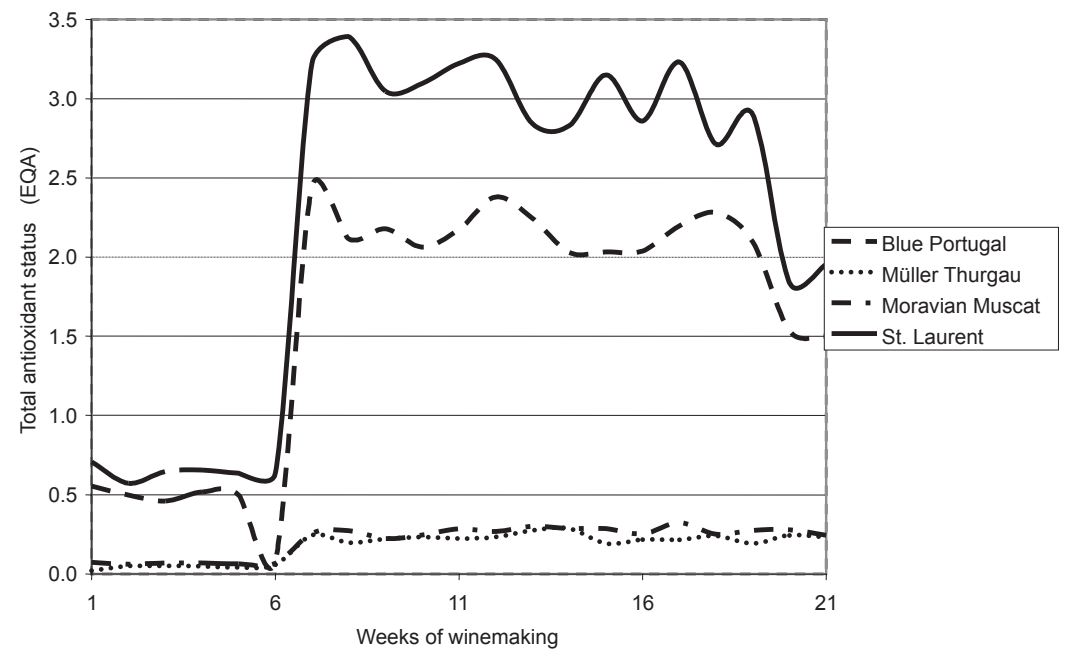

Figure 8 TAS of wines during the winemaking process analyzed by DPPH assay. 


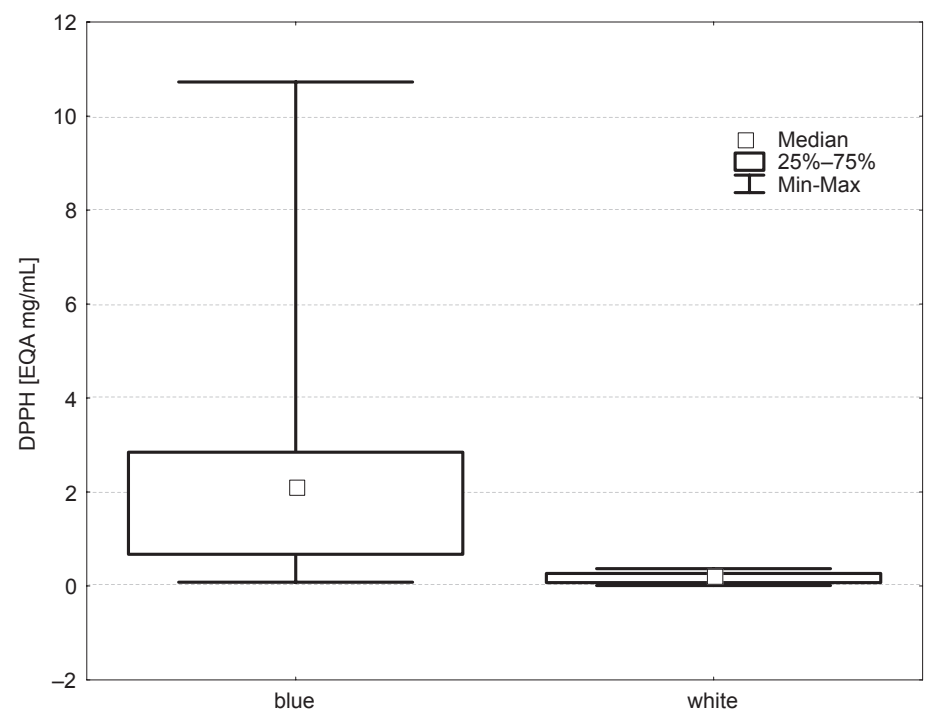

Figure 9 Comparison of TAS of vine varieties determined by DPPH assay.

maceration in particular affects the total polyphenol content in red wines. Differences in the anthocyanin and tannin extractability in grapes during the wine-making process seem to be one of the main factors affecting anthocyanin and polyphenol content of wines. ${ }^{114,115}$ Our results are in good accordance with the results obtained by Villaño and colleagues ${ }^{116}$ and confirm the impact of oenological practices on the TAS of wines determined by ORAC, DPPH, and ABTS. The maceration and fermentation methods used for red wines (cold maceration for 14 days in our study) have a positive effect on the antioxidant potential. Free anthocyanins fraction is main responsible for of the total antioxidant capacity and scavenger activity of red wines. ${ }^{117}$

Another very important factor influencing the TAS results (determined by ABTS and DPPH assays) in the study was the addition of $\mathrm{SO}_{2}$, which acts both as a reducing agent and provides antibacterial effects. The sharp TAS increase recorded between weeks 6 and 7 we ascribe mainly to the addition of $\mathrm{SO}_{2}$. From the linear correlation and regression analysis of the ABTS and DPPH assays of all wines, a medium correlation between ABTS and DPPH values has been found $\left(r^{2}=0.7156\right.$ and $\left.r=0.8459, y=1.6597+1.3889 x\right)$.

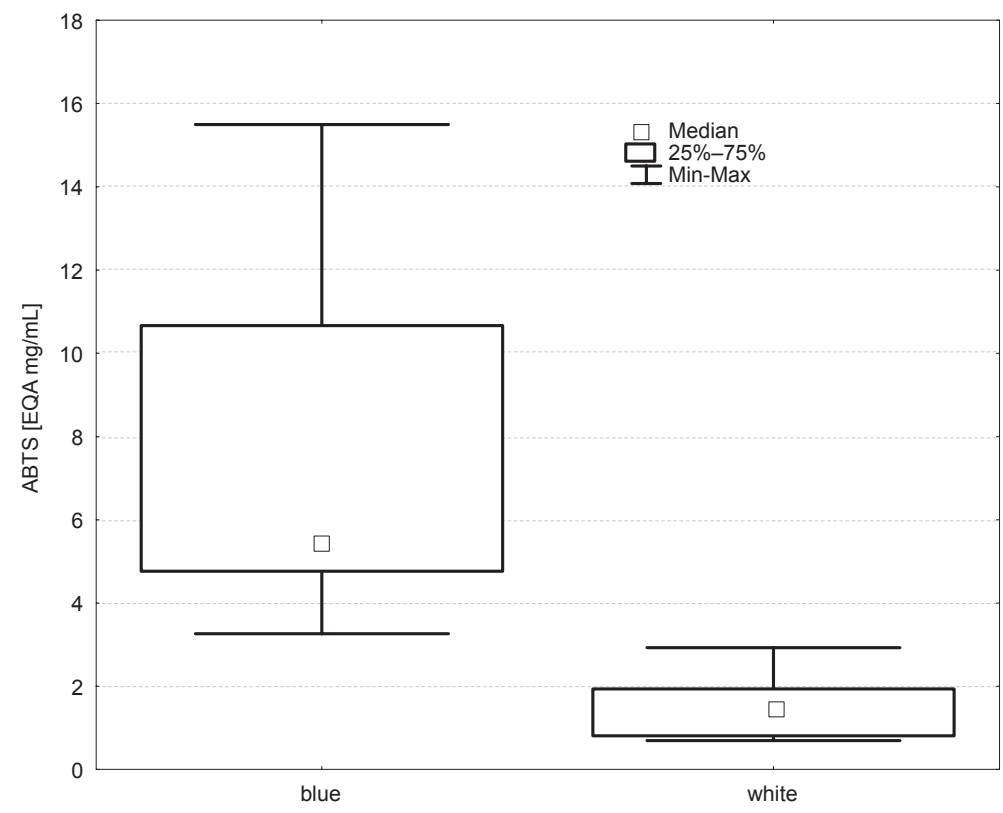

Figure 10 Comparison of TAS of vine varieties determined by ABTS assay. 
In red wines (blue vine varieties), the results were similar (Figure 11), and in white wines (white vine varieties), only a very weak correlation could be found. However, the lack of strong correlation between these two assays is likely attributable to the fact that every individual phenol compound contained in wine causes a different response to the specific radical used in the assay. These different phenol compounds contained in different concentrations depend on the selected technological procedure and duration of its individual phases (especially the period of fermentation, period of remaining in the barrel, and storage temperature). A similar lack of correlation between the TAS measured by the Trolox equivalent antioxidant capacity (TEAC) assay and the other assays (ABTS, FRAP [ferric reducing ability of plasma]) was reported recently. ${ }^{118} \mathrm{ABTS}^{\cdot+}$ and $\mathrm{DPPH}$ radicals have a different stereochemical structure and another method of genesis and thus they lend, after the reaction with the antioxidants, a qualitatively different response to the inactivation of their radical.

According to used winemaking technologies total antioxidant capacity determined by a chemiluminiscence assay also suffered a decrease; the highest decrease (30\%-50\%) was found after the clarification procedure, which may be due to the fining agents used and to oxygen contact. ${ }^{119}$ The possible industrial use of three previously selected Saccharomyces cerevisiae in musts derived from Tempranillo and Cabernet Sauvignon has been investigated recently. ${ }^{120}$ With the exception of hydroxycinnamic acids, no particular influence of the yeast strain was observed on the remaining nonanthocyanin phenol compounds. Pyranoanthocyanins and metabolites resulting from the alcoholic fermentation such as tyrosol and tryptophol, seemed to be more influenced by the must composition and $\mathrm{pH}$, and thus, by the grape variety, than by the yeast strain. According to technologically different winemaking procedures of white and red wines (in white wine vinification mashing is lacking) it was found that at the end of the winemaking process red wines contained on average $1.426 \mathrm{~g} / \mathrm{L}$ TP, whereas white wines only $0.162 \mathrm{~g} / \mathrm{L} .{ }^{121}$ Thus, red wines contained on average two times more TP in comparison with grape must at the beginning of winemaking, whereas TP content decreased to $86 \%$ of origin content in grape musts. The highest TP contents were found in Pinot Noir $(1.935 \mathrm{~g} / \mathrm{L})$, Zweigeltrebe $(1.522 \mathrm{~g} / \mathrm{L})$ and Blue Portugal $(1.318 \mathrm{~g} / \mathrm{L})$. Analysis of variance (Scheffé test) at level of significance $\mathrm{p}<0.05$ showed statistically high significance between red and white wines in TP content, Zweigeltrebe and all other varieties, St. Laurent and Blue Portugal from all other varieties except Pinot Noir. Variance analysis among wine growing areas also confirmed highly significant differences. The obtained results confirm the suggestions ${ }^{24}$ that the extraction of the phenolics was influenced by vinification procedure, grape quality, and grape variety. We can confirm the high influence of winemaking techniques on the polyphenolic composition as it has been referred to in specific Croatian wines. ${ }^{33}$ White and red wines differed significantly in TP content course during the vinification process. In all measured cases from the preparation of must and its fermentation

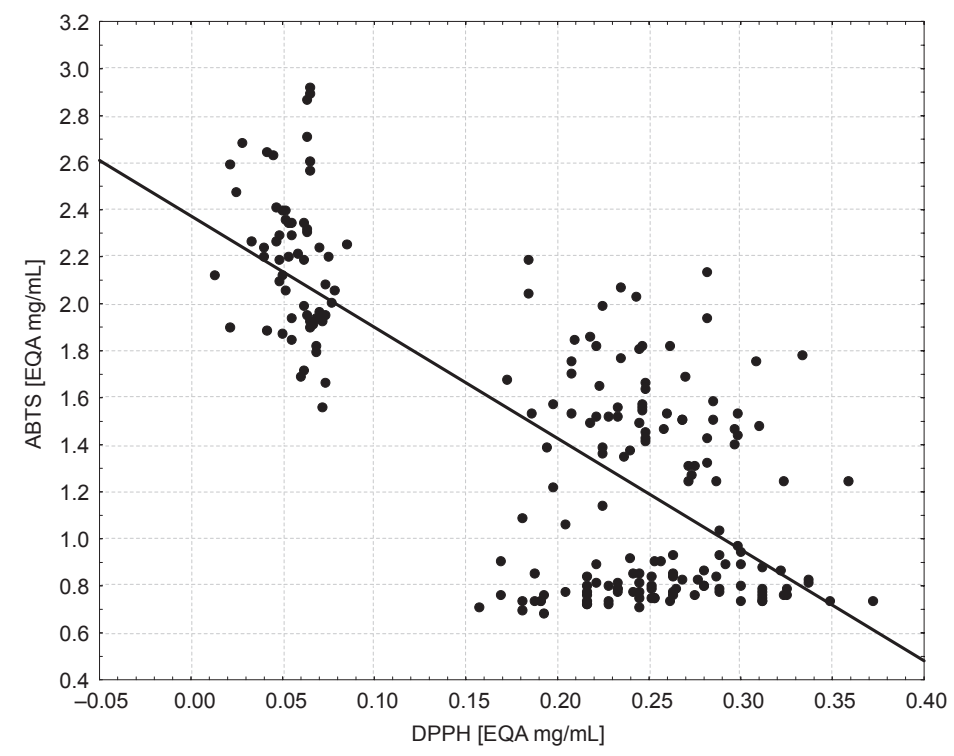

Figure II Comparison of ABTS and DPPH assays of blue vine varieties. 
in October moderate increase could be seen followed by almost constant content during further fermentation and maturation (November 2004-February 2005), followed finally by moderate decrease in March-April, 2005 during and after bottling. TP content changes in white wines during their vinification were insignificant. On the contrary, the procedures of winemaking of red wines are characterized by dramatic changes in their TP content. Maceration and mashing in October was characterized by moderate or medium TP and AA increase, while during fermentation in November-December an intense increase occurred followed by constant content or its moderate decrease during the January-March, 2005 period (maturation of wine) and then decrease in April (bottling and aging). As suggested, ${ }^{34}$ aging is the main factor influencing the antioxidant activity and TP contents of wines. During maturation, quantitative changes of catechins and oligomeric procyanidins were recorded. ${ }^{35}$ Relative constant total polyphenol content in our results is in accordance with results of Echeverry and colleagues, ${ }^{36}$ suggesting the relevance of qualitative changes of phenolics. It could be concluded that red and white wines differ not only in final contents of phenolics, but also in their extreme increase in red wines during fermentation. Different evolution patterns during aging depending on the grape variety were also confirmed. ${ }^{39}$ Decrease is caused mainly by flavanols condensation reactions. The impact of enological practices included maceration for red wines, pressing degree for white wines and clarification in both types of wines on antioxidant activity of wines has been evaluated recently. ${ }^{116}$ Maceration time had a positive effect on antioxidant potential of red wines depending on the variety and a pressure increase caused higher antioxidant activity of white wines. Red wines prepared from a single batch of Vinhão grapes treated with fining agents (polyvinylpyrrolidine, gelatin, egg albumin, and casein) as well as by carbonic maceration tended to have somewhat lower anthocyanin levels, but after two years storage the color density differences were negligible. ${ }^{122}$

Analysis of variance (Scheffé test) at level of significance $\mathrm{p}<0.05$ showed statistically high significance differences of AA between red and white wines. AA increased during the wine-making process, especially in Zweigeltrebe, St. Laurent, and Pinot Noir wines, suggesting thus better AA of wines compared with grape juices at the beginning of the wine-making process. ${ }^{123}$ The highest increase was determined during fermentation and maturation of wine.

Evaluation of stilbene levels ${ }^{124}$ in grape skins of three Vitis vinifera varieties and in their corresponding wines made by traditional winemaking technologies revealed that there was a significant correlation between the concentration of total piceid in grape skins and that in the respective wine.

In twelve bottles of Traminer (vintage 2000, late harvest, wine growing area Žernoseky), total content of polyphenols (TP) and resveratrol (RES) were investigated to determine the variability of the content of measured substances in various bottles of the same batch and from the same manufacturer. ${ }^{125}$ Although the bottles were of the same batch with exactly the same conditions for bottling and bottle storage, the content of TP and RES slightly oscillated. The differences in the content of measured substances could be likely explained by storage and transport conditions (bottles placed in the upper part of a storage area are more exposed to light and temperature changes than bottles stored in lower layers. The packaging material can also influence the content of the measured substances. The outer conditions (light and heat exposure) can cause the degradation of anthocyanins. ${ }^{126}$ It is possible to conclude that the light exposure causes significant changes for anthocyanins, which can cause the differences in the content of total polyphenols. As it was determined in young red wines during 26 months of aging in bottle, ${ }^{127}$ total anthocyanins markedly decreased. The occurrence of condensation reactions during aging in bottle was suggested, due to the disappearance of monomeric anthocyanins, an increase of catechins and procyanidins and a decrease of low-polymerized polyphenols. Lately the relationships between the color parameters and the phenol components (anthocyanins, pyranoanthocyanins, hydroxybenzoic and hydroxycinnamic acids, flavanols and flavonols) of young red wines were investigated. ${ }^{128}$ It was found that for each variety the color parameters were correlated with the anthocyanins during aging in bottles. Finally, by the application of polynomial regression analysis, both anthocyanins (simple glucosides and acetyl-glucosides) and pyranoanthocyanins (anthocyanin-pyruvic acid adducts) were selected as the variables that best described the different color parameters during aging in bottles. The level of monomeric phenolics and low molecular-weight phenol oligomers decreases with age, while the level of high molecular-weight phenolics increases. ${ }^{129}$ The total color of wines is an aggregate number of three components: copigmentation $(8 \%-30 \%)$, total free anthocyanins $(24 \%-35 \%)$, and polymeric pigment $(35 \%-63 \%) .{ }^{130}$ The level of copigmentation can be almost completely described by the levels of monomeric pigments and not by the tannin content as has often been suggested. A progressive decline in both antioxidant capacity and total anthocyanin content of a grape skin ingredient (43\% and 40\% 
decrease, respectively) was observed over a 60 day storage period $\left(45^{\circ} \mathrm{C}\right.$ and $75 \%$ relative humidity), demonstrating its weak stability under these conditions. ${ }^{128}$ The pyranoanthocyanins of cyanidin, petunidin, malvidin and pelargonidin showed a high capacity to scavenge superoxide anion radicals but did not scavenge hydroxyl radicals. Current data indicate that formation of anthocyanin adducts with pyruvic acid, which may occur during wine aging or fruit juice processing, decreases the hydroxyl and superoxide anion scavenging and thus could decrease the antioxidant potential of these compounds. ${ }^{131}$ Younger wines had higher concentrations of copigmented, monomeric and total anthocyanins than did older wines. ${ }^{132}$ The ratios anthocyanins/proanthocyanidins and anthocyanins/(proanthocyanidins + catechins) are proposed as probable indicators of the aptitude for wine aging. ${ }^{133}$ The assay methods ${ }^{134}$ on red wines aged in barrels and botttles showed different behaviors for the same wines, thus the young wines presented higher indices for ABTS, DPPH and DMPD (a mechanism that predominates in this assay method, is sharply reduced when it coincides with the formation of more complex and stable compounds, such as newly formed pigments (vitisins, pyro-anthocyanins, arylanthocyanins), whereas those that were aged showed higher indices for antioxidant activity. The latest reported results ${ }^{135}$ dealing with the investigation of polyphenol content, antioxidant activity, reducing power, color and changes during storage of selected Hellenic varietal white wines in bottles for the period over nine month showed that the contents of most studied phenols (caftaric, coutaric, fertaric and gallic acids, (+)-catechin, (-)-epicatechin)) diminished with time (with exceptions of caffeic, ferulic and $p$-coumaric acid), but antioxidant activity increased with storage whereas reducing power was not significantly affected. Accelerated browning increased the concentrations of hydroxycinnamic acids and gallic acid while (-)-epicatechin decreased.

\section{Effect of antioxidants from winemaking wastes}

The feasibility of extracting antioxidant compounds from winemaking wastes (grape stalks and marc) by solvent extraction was recently assessed. ${ }^{136}$ Together with the type of raw material they also investigated the influence of some process parameters on final antioxidants yields and extract purity: a treatment, type of solvent (ethanol or a mixture of ethylacetate: water $=9: 1)$, temperature $\left(28^{\circ} \mathrm{C}\right.$ or $\left.60^{\circ} \mathrm{C}\right)$ and length of maceration (5 or $24 \mathrm{~h})$. Solvent and temperature were statistically influent $(\mathrm{p}<0.05)$, and the yields were higher with ethanol (but with lower purities) and at $60{ }^{\circ} \mathrm{C}$. The results of Bonilla and colleagues ${ }^{137}$ revealed a higher extraction of phenol compounds from red grape marc for use as food lipid antioxidants by the ethyl acetate acting on crushed marc, so the cost of this last operation can be largely compensated. Antioxidant activity of the phenols of the extract was close to that of BHT, mostly because of its catechin content. Grape cane waste could be used as a potential source of high-value phytochemicals with medicinal and anti-phytopathogenic applications. ${ }^{58}$ Extraction yields of trans-resveratrol and trans-viniferin from Vitis vinifera $\mathrm{cv}$. Pinot Noir grape cane were $3.45 \pm 0.04$ and $1.30 \pm 0.07 \mathrm{mg} / \mathrm{g} \mathrm{DM}$, respectively. The study suggested that these compounds can be quantitatively extracted from grape cane residue using low-cost, environmentally benign, and nontoxic aqueous alcoholic solvent systems such as ethanol:water mixtures. Ethanol extract of winery waste exhibited the highest antioxidant activity ${ }^{138}$ compared to the other solvent extracts, to synthetic food antioxidants BHT, ascorbyl palmitate and to the natural food antioxidant, vitamin E. High performance liquid chromatography (HPLC) analysis of the extracts showed that gallic acid, catechin, and epicatechin were the major phenol compounds in winery waste. Hydroxytyrosol, tyrosol, anthocyanidin glycosides, and various phenol acids such as caffeic, syringic, vanillic, $p$-coumaric and $o$-coumaric acids were also identified. Seeds of red grape varieties as dietary supplement could be recommend ${ }^{139}$ due to high amount of total phenolic contentand antioxidant activity. While (+)-catechin (4.71-23.8 mg/g seed) was found as main flavanol, galloylated catechin monomer and dimeric procyanidin amounts varied between $2.89-17.2$ and $0.97-2.97 \mathrm{mg} / \mathrm{g}$ seed, respectively. Other two by-products of the winemaking process, namely stem and pomace, of Manto Negro red grape variety native to Mallorca have been characterized recently. ${ }^{140}$ These products present considerably high contents in dietary fibre with associated polyphenols and excellent antioxidant properties, particularly in the case of the stem, which confer on them a wide range of applications as food ingredients. The pomace has high protein (12.2\%), oil (13.5\%) values, and the stem large amounts of extractable polyphenols (11.6\%). Red grape wine lees added to ice cream $^{141}$ improved its rheological properties and increased radical scavenging activity.

\section{Conclusion}

In conclusion, the present findings support our knowledge from experimental and epidemiological studies, suggesting that the supply of antioxidant phenols through a moderate daily consumption of red wines may provide additional protection against in vivo oxidation and other damages of cellular bioconstituents. Thus, vine-breeders and wine 
producers can try to produce grape products and wines with the highest content of phenolic antioxidants and antioxidant activity, as well as with the optimal organoleptic properties.

\section{Disclosure}

The authors report no conflicts of interest in this work.

\section{Acknowledgments}

This study was supported by the Research Project of the Ministry of Education, Youth and Sports of the Czech Republic, MSM 6046070901.

\section{References}

1. Guarda E, Godoy I, Foncea R, et al. Red wine reduces oxidative stress in patients with acute coronary syndrome. Int J Cardiol. 2005;104(1):35-38.

2. Di Majo D, Guardia ML, Giammanco S, Neve LL, Giammanco M. The antioxidant capacity of red wine in relationship with its polyphenolic constituents, Food Chem. 2008;111(1):45-49.

3. Fernàndez-Pachòn MS, Villano D, Garcia-Parrilla MC, Troncoso AM. Antioxidant activity of wines and relation with their polyphenolic composition. Anal Chim Acta. 2004;513(1):113-118.

4. Landrault N, Poucheret P, Ravel P, Gasc F, Cros G, Teissedre P. Antioxidant capacities and phenolics levels of French wines from different varieties and vintages. J Agric Food Chem. 2001;49(7):3341-3348.

5. Vinson JA, Teufel K, Wu N. Red wine, dealcoholized red wine, and especially grape juice, inhibit atherosclerosis in a hamster model. Atherosclerosis. 2001;156(1):67-72.

6. Pinder RM, Sandler M. Alcohol, wine and mental health: focus on dementia and stroke. J Psychopharm. 2004;18(4):449-456.

7. Bartolomé B, Nuñez V, Monagas M, Gómez-Cordovés C. In vitro antioxidant activity of red grape skins. Eur Food Res Technol. 2004;218(2):173-177.

8. Serafini M, Maiani M, Ferro-Luzzi A. Alcohol-free red wine enhances plasma antioxidant capacity in humans. J Nutr. 1998;128(6):1003-1007.

9. Yilmaz Y, Toledo RT. Health aspects of functional grape seed constituents. Trends Food Sci Technol. 2004a;15(9):422-433.

10. Yilmaz Y, Toledo RT. Major flavonoids in grape seeds and skins: Antioxidant capacity of catechin, epicatechin, and gallic acid. J Agric Food Chem. 2004;52(2):255-260.

11. Bianchini F, Vainio H. Wine and resveratrol: mechanismus of cancer prevention? Eur J Canc Prev. 2003;12(5):417-425.

12. Karakaya S, El SN, Tas AA. Antioxidant activity of some foods containing phenolic compounds. Int J Food Sci Nutr. 2001;52(6):501-508.

13. Borbalán AMA, Zorro L, Guillén DA, Barroso CG. Study of the polyphenol content of red and white grape varieties by liquid chromatography - mass spectrometry and its relationship to antioxidant power. J Chromatog A. 2003;1012(1):31-38.

14. De Beer D, Joubert E, Gelderblom WCA, Manley M. Antioxidant activity of South African red and white cultivar wines: Free radical scavenging. J Agric Food Chem. 2003;51(4):902-909.

15. Dugo G, Salvo F, Dugo P, La Torre GL, Mondello L. Antioxidants in Sicilian wines: Analytic and compositive aspects. Drugs Exp Clin Res. 2003;29(5-6):189-202.

16. Yildirim HK, Akcay YD, Guvenc U, Altindisli A, Sozmen EY. Antioxidant activities of organic grape, pomace, juice, must, wine and their correlation with phenolic content. Int J Food Sci Technol. 2005;40(2):133-142.

17. Chicón RM, Sanchez-Palomo E, Cabezudo MD. The colour and polyphenol composition of red wine varieties in Castilla - La Mancha (Spain). Afinidad. 2002;59(500):435-443.

18. Kammerer D, Claus A, Carle R, Schieber A. Polyphenol screening of pomace from red and white grape varieties (Vitis vinifera L.) by HPLCDAD-MS/MS. J Agric Food Chem . 2004;52(14):4360-4367.
19. Baydar NG, Ozkan G, Sagdic O. The phenolic contents and antibacterial activities of grape (Vitis vinifera L.) extracts. Food Control. 2004; 15(5):335-339.

20. Katalinić V, Milos M, Modun D, Musić I, Boban M. Antioxidant effectiveness of selected wines in comparison with (+)-catechin. Food Chem. 2004;86(4):593-600.

21. Filip V, Plocková M, Šmidrkal J, Špičková Z, Melzoch K, Schmidt S. Resveratrol and its antioxidant and antimicrobial effectiveness. Food Chem. 2003;83(4):585-593.

22. Burkitt MJ, Duncan J. Effects of trans-resveratrol on copper-dependent hydroxyl-radical formation and DNA-damage: evidence for hydroxylradical scavenging and a novel, glutathione-sparing mechanism of action. Arch Biochem Biophys. 2000;381(2):253-263.

23. Sandler M, Pinder R, editors. Wine: A Scientific Explanation. New York: Taylor and Francis; 2003.

24. Burns J, Gardner PT, Metthews D, et al. Extraction of phenolics and changes in antioxidant activity of red wines during vinification. J Agric Food Chem. 2001;49(12):5797-5808.

25. Paganga G, Miller N, Rice-Evans CA. The polyphenolic content of fruit and vegetables and their antioxidant activities. What does a serving constitute? Free Rad Res. 1999;30(2):153-162.

26. Banini AE, Boyd LC, Allen JC, Hengameh GA, Derrick LS. Muscadine grape products intake, diet and blood constituents of non-diabetics and type 2 diabetic subjects. Nutrition. 2006;22(11-12):1137-1145.

27. Balestrieri ML, Fiorito C, Crimi E, et al. Effect of red wine antioxidants and minor polyphenolic constituents on endothelial progenitor cells after physical training in mice. Int J Cardiol. 2008;126(2):295-297.

28. Soleas GJ, Grass L, Josephy PD, Goldberg DM, Diamandis EP. A comparison of the anticarcinogenic properties of four red wine polyphenols. Clin Biochem. 2002;35(2):119-124.

29. Argyri K, Komaitis M, Kapsokefalou M. Iron decreases the antioxidant capacity of red wine under conditions of in vitro digestion. Food Chem. 2006;96(2):281-289.

30. Saura-Calixto F, Díaz-Rubio ME. Polyphenols associated with dietary fibre in wine. A wine polyphenols gap? Food Res Int. 2007;40(5):613-619.

31. Faitová K, Hejtmánková A, Lachman J, Pivec V, Dudjak J. The contents of total polyphenolic compounds and trans-resveratrol in white Riesling originated in the Czech Republic. Czech J Food Sci. 2004;22(6):215-221.

32. Vivar-Quintana AM, Santos-Buelga C, Rivas-Gonzalo JC. Anthocyaninderived pigments and colour of red wines. Anal Chim Acta. 2002; 458(1):147-155.

33. Budic-Leto I, Lovric T, Pezo I, Kljusuric JG. Study of dynamics of polyphenol extraction during traditional and advanced maceration processes of the Babic grape variety. Food Technol Biotechnol. 2005;43(1):47-53.

34. Pellegrini N, Simonetti P, Gardana C, Brenna O, Brighenti F, Pietta P. Polyphenol content and total antioxidant activity of Vini novelli (young red wines). J Agric Food Chem. 2000;48(3):732-735.

35. Jordao AM, Ricardo-Da-Silva JM, Laureano O. Evolution of catechins and oligomeric procyanidins during grape maturation of Castelao Frances and Touriga Francesa. Am J Enol Vitic. 2001;52(3):230-234.

36. Echeverry C, Ferreira M, Reyes-Parada M, et al. Changes in antioxidant capacity of Tannat red wines during early maturation. J Food Eng. 2005;69(2):147-154

37. Pozo-Bayon MA, Hernandez MT, Martin-Alvarez PJ, Polo MC. Study of low molecular weight phenolic compounds during the aging of sparkling wines manufactured with red and white grape varieties. J Agric Food Chem. 2003;51(7):2089-2095.

38. Esparza I, Salinas I, Caballero I, et al. Evolution of metal and polyphenol content over a 1-year period vinification: sample fractionation and correlation between metals and anthocyanins. Anal Chim Acta. 2004;524(1-2):215-224.

39. Monagas M, Bartolomé B, Gomez-Cordoves C. Evolution of polyphenols in red wines from Vitis vinifera L. during aging in the bottle - II. Non-anthocyanin phenolic compounds. Eur Food Res Technol. 2005;220(3-4):331-340. 
40. Zafrilla P, Morillas J, Mulero J, et al. Changes during storage in conventional and ecological wine: Phenolic content and antioxidant activity. J Agric Food Chem. 2003;51(16):4694-4700.

41. Revilla E, Ryan JM. Analysis of several phenolic compounds with potential antioxidant properties in grape extracts and wines by highperformance liquid chromatography - photodiode array detection without sample preparation. J Chromatog A. 2000;881(1-2):461-469.

42. Teissedre PL, Landrault N. Wine phenolics: contribution to dietary intake and bioavailability. Food Res Int. 2000;33(6):461-467.

43. Sakkiadi AV, Haroutounian SA, Stavrakakis MN. Direct HPLC assay of five biologically interesting phenolic antioxidants in varietal Greek red wines. Lebensm-Wiss Technol. 2001;34(6):410-413.

44. Mc Dougall GJ, Fyffe S, Dobson P., Stewart D. Anthocyanins from red wine - Their stability under simulated gastrointestinal digestion. Phytochemistry. 2005;66(21):2540-2548.

45. Krisa S, Téguo PW, Decendit A, Deffieux G, Vercauteren J, Mérillon JM. Production of ${ }^{13} \mathrm{C}$-labelled anthocyanins by Vitis vinifera cell suspension cultures. Phytochemistry. 1999;51(5):651-656.

46. Jacob JK, Hakimuddin F, Paliyath G, Fisher H. Antioxidant and antiproliferative activity of polyphenols in novel high-polyphenol grape lines. Food Res Int. 2008;41(4):419-428.

47. Asenstorfer RE, Jones GP. Charge equilibria and $\mathrm{p} K$ values of 5-carboxypyranomalvidin-3-glucoside (vitisin A) by electrophoresis and absorption spectroscopy. Tetrahedron. 1997;63(22):4788-4792.

48. Negro C, Tommasi L, Miceli A. Phenolic compounds and antioxidant activity from red grape marc extracts. Biores Technol. 2003;87(1):41-44.

49. Valentão P, Seabra RM, Lopes G, et al. Influence of Dekkera bruxellensis on the contents of anthocyanins, organic acids and volatile phenols of Dão red wine. Food Chem. 2007;100(1):64-70.

50. Silva LR, Andrade PB, Valentão P, Seabra RM, Trujillo ME, Velázguez E. Analysis of non-coloured phenolics in red wine: Effect of Dekkera bruxellensis yeast. Food Chem. 2005;89(2):185-189.

51. Gutiérrez IH, Lorenzo ESP, Espinosa AV. Phenolic composition and magnitude of copigmentation in young and shortly aged red wines made from the cultivars, Cabernet Sauvignon, and Syrah. Food Chem. 2005;92(2):269-283.

52. Álvarez I, Aleixandre JL, García MJ, Lizama V. Impact of prefermentative maceration on the phenolic and volatile compounds in Monastrell red wines. Anal Chim Acta. 2006;563(1-2):109-115.

53. Bravo MN, Silva S, Coelho AV, Boas LV, Bronze MR. Analysis of phenolic compounds in Muscatel wines produced in Portugal. Anal Chim Acta. 2006;563(1-2):84-92.

54. Frémont L. Minireview. Biological effects of resveratrol. Life Sci. 2000;66(8):663-673.

55. Schmandke H. Resveratrol and piceid in grapes and soybeans and products made from them. Ernähr-Umsch. 2002;49(9):349-352.

56. Šmidrkal J, Filip V, Melzoch K, Hanzlíková I, Buckiová D, Kriša B. Resveratrol. Chem Listy. 2001;95(10):602-609.

57. Barger JL, Kayo T, Vann JM, et al. A low dose of dietary resveratrol partially mimics caloric restriction and retards aging parameters in mice. PloS ONE. 2008;3(6):e2264.

58. Rayne S, Karacabey E, Mazza G. Grape cane waste as a source of trans-resveratrol and trans-viniferin: High-value phytochemicals with medicinal and anti-phytopathogenic applications. Ind Crops Prod. 2008;27(3):335-340.

59. La Torre GL, Saitta M, Vilasi F, Pellicanò T, Dugo G. Direct determination of phenolic compounds in Sicilian wines by liquid chromatography with PDA and MS detection. Food Chem. 2006;94(4):640-650.

60. Nikfardjam MSP, László M, Avar P, Figler M, Ohmacht R. Polyphenols, anthocyanins, and trans-resveratrol in red wines from the Hungarian Villa'ny region. Food Chem. 2006;98(3):453-462.

61. Šulc M, Lachman J, Hejtmánková A, Orsák M. Relationship between antiradical activity, polyphenolic antioxidants and free trans-resveratrol in grapes (Vitis vinifera L). Hortic Sci (Prague). 2005;32(4):154-162.

62. Peña-Neira A, Hernández T, García-Valejjo C, Suarez JA. A survey of phenolic compounds in Spanish wines of different geographical origin. Eur Food Res Technol. 2000;210(6):445-448.
63. Cantos E, Espin JC, Tomas-Barberan FA. Varietal differences among the polyphenol profiles of seven table grape cultivars studied by LC/ DAD/MS/MS. J Agric Food Chem. 2002;50(20):5691-5696.

64. Todaro A, Palmeri R, Barbagallo, RN, Pifferi PG, Spagna G. Increase of trans-resveratrol in typical Sicilian wine using $\beta$-Glucosidase from various sources. Food Chem. 2008;107(4):1570-1575.

65. Belhadj A, Telef N, Saigne C, et al. Effect of methyl jasmonate in combination with carbohydrates on gene expression of PR proteins, stilbene and anthocyanin accumulation in grapevine cell cultures. Plant Physiol Biochem. 2008;46(4):493-499.

66. Nikfardjam MSP, László G, Dietrich H. Resveratrol-derivatives and antioxidative capacity in wines made from botrytized grapes. Food Chem. 2006;96(1):74-79.

67. Dani C, Oliboni LS, Vanderlinde R, Bonatto D., Salvador M, Henriques JAP. Phenolic content and antioxidant activities of white and purple juices manufactured with organically- or conventionally-produced grapes. Food Chem Toxicol. 2007;45(12):2574-2580.

68. Fuhrman B, Volkova N, Suraski A, Aviram M. White wine with red wine-like properties: increased extraction of grape skin polyphenols improves the antioxidant capacity of the derived white wine. $J$ Food Agric Chem. 2001;49(7):3164-3168.

69. Talcott ST, Peele JE, Brenes CH. Red clover isoflavonoids as anthocyanin color enhancing agents in muscadine wine and juice. Food Res Int. 2005;38(10):1205-1212.

70. Arnous A, Makris DP, Kefalas P. Effect of principal polyphenolic components in relation to antioxidant characteristics of aged red wines. J Agric Food Chem. 2001;49(12):5736-5742.

71. Kallithraka S, Mohdaly AA, Makris DP, Kefalas P. Determination of major anthocyanin pigments in Hellenic native grape varieties (Vitis vinifera sp.). Association with antiradical activity. J Food Comp Anal. 2005;18(5): 375-386.

72. Durak I, Avci A, Kacmaz M, Buyukkocak S., Cimen MYB, Elgun S, Ozturk HS. Comparison of antioxidant potentials of red wine, white wine, grape juice and alcohol. Curr Med Res Opin. 1999;15(4):316-320.

73. Dávalos A, Bartolomé B, Gómez-Cordovés C. Antioxidant properties of grape juices and vinegars. Food Chem. 2005;93(2):325-330.

74. Bors W, Michel C. Chemistry of the antioxidant effect of polyphenols. Alcohol and Wine in Health and Disease. Ann N Y Acad Sci. 2002;957:57-69.

75. Murcia MA, Martinez-Tome M. Antioxidant activity of resveratrol compared with common food additives. J Food Prot. 2001;64(3):379-384.

76. De Beer D, Joubert E, Marais J, Manley M. Unravelling the total antioxidant capacity of pinotage wines: Contribution of phenolic compounds. J Agric Food Chem. 2006;54(8):2897-2905.

77. Burns J, Gardner PT, O'Neil J, et al. Relationship among antioxidant activity, vasodilatation capacity, and phenolic content of red wines. J Agric Food Chem. 2000;48(2):220-230.

78. Guendez, R, Kallithraka S, Makris DP, Kefalas P. Determination of low molecular weight polyphenolic constituents in grape (Vitis vinifera sp.) seed extracts: Correlation with antiradical activity. Food Chem. 2005;89(1):1-9.

79. Munoz-Espada AC, Wood KV, Bordelon B, Watkins BA. Anthocyanin quantification and radical scavenging capacity of Concord, Norton, and Marechal Foch grapes and wines. J Agric Food Chem. 2004;52(22):6779-6786.

80. Sanchez-Moreno C, Cao GH, Ou BX, Prior RL. Anthocyanin and proanthocyanidin content in selected white and red wines. Oxygen radical absorbance capacity comparison with nontraditional wines obtained from highbush blueberry. J Agric Food Chem. 2003;51(17):4889-4896.

81. Dell' Agli M, Buscialà A, Bosisio E. Vascular effects of wine polyphenols. Cardiovas Res. 2004;63(4):593-602.

82. Minussi RC, Rossi M, Bologna L, et al. Phenolic compounds and total antioxidant potential of commercial wines. Food Chem. 2003;82(3):409-416.

83. De Beer D, Joubert E, Gelderblom WCA, Manley M. Antioxidant activity of South African red and white cultivar wines and selected phenolic compounds: In vitro inhibition of microsomal lipid peroxidation. Food Chem. 2005;90(4):569-577. 
84. Rodrigo R, Castillo R, Carrasco R, Huerta P, Moreno M. Diminution of tissue lipid peroxidation in rats is related to the in vitro antioxidant capacity of wine. Life Sci. 2005;76(8):889-900.

85. Cooke D, Steward WP, Gescher AJ, Marczylo T. Anthocyans from fruits and vegetables - Does bright colour signal cancer chemopreventive activity? Eur J Canc. 2005;41(13): 1931-1940.

86. Šulc M, Lachman J, Masopustová R. Effect of red wine from the Mělník vineyard region on antioxidant activity of blood plasma of Rattus norvegicus (Wistar). In: Proceedings of Biotechnology. 2006, Feb 15-16, South Bohemian University, České Budějovice: 409-411.

87. Modun D, Musić I, Vuković J, et al. The increase in human plasma antioxidant capacity after red wine consumption is due to both plasma urate and wine polyphenols. Atherosclerosis. 2008;197(1):250-256.

88. Lachman J, Šulc M, Hejtmánková A, Pivec V, Orsák M. Content of polyphenolic antioxidants and trans-resveratrol in grapes of different varieties of grapevine (Vitis vinifera L.). Hortic Sci (Prague). 2004;31(2):63-69.

89. Gonzáles-Neves G, Charamelo D, Balado J, et al. Phenolic potential of Tannat, Cabernet-Sauvignon and Merlot grapes and their correspondence with wine composition. Anal Chim Acta. 2004;513(1): 191-196.

90. Orak HH. Total antioxidant activities, phenolics, anthocyanins, polyphenoloxidase activities of selected red grape cultivars and their correlations. Sci Hortic. 2007;111(3):235-241.

91. Kolouchová-Hanzlíková I, Melzoch K, Filip V, Šmidrkal J. Rapid method for resveratrol determination by HPLC with electrochemical and UV detections in wines. Food Chem. 2004;87(1):151-158.

92. Gürbüz O, Göçmen D, Dağdelen F, et al. Determination of flavan-3-ols and trans-resveratrol in grapes and wine using HPLC with fluorescence detection. Food Chem. 2007;100(2):518-525.

93. Woraratphoka J, Intarapichet KO, Indrapichate K. Phenolic compounds and antioxidative properties of selected wines from the northeast of Thailand. Food Chem. 2007;104(4):1485-1490.

94. Paixão N, Perestrelo R, Marques JC, Câmara JS. Relationship between antioxidant capacity and total phenolic content of red, rosé and white wines. Food Chem. 2007;105(1):204-214.

95. Uhlig BA, Clingeleffer PR. Ripening characteristics of the fruit from Vitis vinifera L. drying cultivars sultana and Merbein seedless under furrow irrigation. Am J Enol Vitic. 1998;49(4):375-382.

96. Makris DP, Psarra E, Kallithraka S., Kefalas P. The effect of polyphenolic composition as related to antioxidant capacity in white wines. Food Res Int. 2003;36(8):805-814.

97. Uhlig BA. Effects of solar radiation on grape (Vitis vinifera L.) composition and dried fruit colour. J Hortic Sci Biotechnol. 1998;73(1):111-123.

98. Kennedy JA, Matthews MA, Waterhouse AL. Effect of maturity and vine water status on grape skin and wine flavonoids. Am JEnol Vitic. 2002;53(4):268-274.

99. Montero C, Cristescu SM, Jimenez JB, et al. trans-Resveratrol and grape disease resistance. A dynamical study by high-resolution laserbased techniques. Plant Physiol. 2003;131(1):129-138.

100. Adrian M, Rajaei H, Jeandet P, Veneau J, Bessis R. Resveratrol oxidation in Botrytis cinerea conidia. Phytopathol. 1998;88(5):472-476.

101. Castellari M, Spinabelli U, Riponi C, Amati A. Influence of some technological practices on the quantity of resveratrol in wine. Ztsch Lebensm Unters- Forsch A. 1998;206(3):151-155.

102. Morales M, Alcántara J, Barceló AR. Oxidation of trans-resveratrol by a hypodermal peroxidase isoenzyme from Gamay rouge grape (Vttis vinifera) berries. Am J Enol Vitic. 1997;48(1):33-39.

103. Abril M, Negueruela AI, Pérez C, Juan T, Estopañán G.. Preliminary study of resveratrol content in Aragón red and rosé wines. Food Chem. 2005;92(4):729-736

104. Kallithraka S, Arvanytoiannis I, El-Zajouli A, Kefalas P. The application of an improved method for trans-resveratrol to determine the origin of Greek red wines. Food Chem. 2001;75(3):355-363.

105. Dadáková E, Vrchotová N, Tř́íska J, Kyseláková M. Determination of free and conjugated quercetin in Moravian red wines. Chem listy. 2003;97(7):558-561.
106. Kallithraka S, Tsoutsouras E, Tzourou E, Lanaridis P. Principal phenolic compounds in Greek red wines. Food Chem. 2006;99(4):784-793.

107. Cimino F, Sulfaro V, Trombetta D, Saija A, Tomaino A. Radicalscavenging capacity of several Italian red wines. Food Chem. 2007; 103(1):75-81.

108. Stervbo U, Vang O, Bonnesen C. A review of the content of the putative chemoprevetive phytoalexin resveratrol in red wine. Food Chem. 2007;101(2):449-457.

109. Roggero JP. Study of the ultraviolet irradiation of resveratrol and wine. J Food Comp Anal. 2000;13(1):93-97.

110. Lachman J, Šulc M, Schilla M. Comparison of the total antioxidant status of Bohemian wines during the wine-making process. Food Chem. 2007;103(3):802-807.

111. De Villiers A, Majek P, Lynen F, Crouch A, Lauer H, Sandra P. Classification of South African red and white wines according to grape variety based on the non-coloured phenolic content. Eur Food Res Technol. 2005;221(3-4):520-528.

112. Fernández-Pachón MS, Villaño D, Troncoso AM, García-Parrilla MC. Determination of the phenolic composition of sherry and table white wines by liquid chromatography and their relation with antioxidant activity. Anal Chim Acta. 2006;563(1-2):101-108.

113. Gómez-Plaza E, Miñano A, López-Roca JM. Comparison of chromatic properties, stability and antioxidant capacity of anthocyanin-based aqueous extracts from grape pomace obtained from different vinification methods. Food Chem. 2006;97(1):87-94.

114. Ortega-Regules A, Romero-Cascales I, Ros-García JM, López-Roca JM, Gómez-Plaza E. A first approach towards the relationship between grape skin cell-wall composition and anthocyanin extractability. Anal Chim Acta. 2006;563(1-2):26-32.

115. Netzel A, Strass G, Bitsch I, Konitz R, Christmann M, Bitsch R. Effect of grape processing on selected antioxidant phenolics in red wine. J Food Eng. 2003;56(2-3):223-228.

116. Villaño D, Fernández-Pachón MS, Troncoso AM, García-Parrilla MC. Influence of enological practices on the antioxidant activity of wines. Food Chem. 2006;95(3):394-404.

117. Rivero-Pérez MD, Muñiz P, González-Sanjosé ML. Contribution of anthocyanin fraction to the antioxidant properties of wine. Food Chem Toxicol. 2008a; doi:10.1016/j.fct.2008.05.014.

118. Wang CC, Chu CY, Chu KO, et al. Trolox-equivalent antioxidant capacity assay versus oxygen radical absorbance capacity assay in plasma. Clin Chem. 2004;50(5):952-954.

119. Girotti S, Fini F, Bolelli L, Savini L, Sartini E, Arfelli G. Chemiluminescent determination of total antioxidant capacity during winemaking. Luminiscence. 2006;21(4):233-238.

120. Monagas M, Gómez-Cordovés C, Bartolomé B. Evaluation of different Saccharomyces cerevisiae strains for red wine-making. Influence on the anthocyanin, pyranoanthocyanin and non-anthocyanin phenolic content and colour characteristics of wines. Food Chem. 2007;104(2):814-823.

121. Lachman J, Šulc M. Phenolics and antioxidant activity of wines during the winemaking process. Bornimer Agrartech Ber. 2006;14(55): $161-168$.

122. Castillo-Sánchez JJ, Mejuto JC, Garrido J, García-Falcón S. Influence of wine-making protocol and fining agents on the evolution of the anthocyanin content, colour and general organoleptic quality of Vinhão wines. Food Chem. 2006;97(1):130-136.

123. Alcolea JF, Cano A, Acosta M, Arnao MB. Determination of the hydrophilic and lipophilic antioxidant activity of white- and red wines during the wine-making process. It J Food Sci. 2003;15(2):207-214.

124. Sun B, Ribes AM, Leandro MC, Belchior AP, Spranger MI. Stilbenes: Quantitative extraction from grape skins, contribution of grape solids to wine and variation during wine maturation. Anal Chim Acta. 2006; 563(1-2):382-390.

125. Faitová K, Hejtmánková A, Lachman J, Dudjak J, Pivec V, Šulc M. Variability of the content of total polyphenols and resveratrol in Traminer bottles of the same batch. Sci Agric Bohem. 2004; 35(2):64-68. 
126. Bakowska A, Kucharska AZ, Oszmianski J. The effects of heating, UV-irradiation, and storage on stability of the anthocyanin - polyphenol copigment complex. Food Chem. 2003;81(3):349-355.

127. Monagas M, Gómez-Cordovés C, Bartolomé B. Evolution of the phenolic content of red wines from Vitis vinifera $\mathrm{L}$. during ageing in bottle. Food Chem. 2006;95(3):405-412.

128. Monagas M, Hernández-Ledesma B, Gómez-Cordovés C, Bartolomé B. Commercial dietary ingredients from Vitis vinifera $L$. leaves and grape skins: Antioxidant and chemical characterization. J Agric Food Chem. 2006;54(2):319-327.

129. Roginsky V, de Beer D, Habertson JF, Kilmartin PA, Barsukoval T, Adams TO. The antioxidant activity of Californian red wines does not correlate with wine age. J Sci Food Agric. 2006;86(5):834-840.

130. Versari A, Boulton RB, Parpinello GP. A comparison of analytical methods for measuring the color components of red wines. Food Chem. 2008;106(1):397-402.

131. Garcia-Alonso M, Rimbach G, Sasai M, et al. Electron spin resonance spectroscopy studies on the free radical scavenging activity of wine anthocyanins and pyranoanthocyanins. Mol Nutr Food Res. 2005;49(12):1112-1119.

132 Cliff MA, King MC, Schlosser J. Anthocyanin, phenolic composition, colour measurement and sensory analysis of $\mathrm{BC}$ commercial red wines. Food Res Int. 2007;40(1):92-100.

133. Pérez-Magariño S, González-San José ML. Polyphenols and colour variability of red wines made from grapes harvested at different ripeness grade. Food Chem. 2006;96(2):197-208.
134. Rivero-Pérez MD, González-Sanjosé ML, Ortega-Herás M, Muñiz P. Antioxidant potential of single-variety red wines aged in the barrel and in the bottle. Food Chem. 2008; doi:10.1016/ j.foodchem.2008.05.013.

135. Kallithraka S, Salacha MI, Tzourou I. Changes in phenolic composition and antioxidant activity of white wine during bottle storage: Accelerated browning test versus bottle storage. Food Chem. 2009;113(2):500-505.

136. Spigno G, Faveri DM. Antioxidants from grape stalks and marc: Influence of extraction procedure on yield, purity and antioxidant power of the extracts. J Food Eng. 2007;78:793-801.

137. Bonilla F, Mayen M, Merida J, Medina M. Extraction of phenolic compounds from red grape marc for use as food lipid antioxidants. Food Chem. 1999;66(2):209-215.

138. Lafka TI, Sinanoglou V, Lazos ES. On the extraction and antioxidant activity of phenolic compounds from winery wastes. Food Chem. 2007;104(3):1206-1214

139. Bozan B, Tosun G, Özcan D. Study of polyphenol content in the seeds of red grape (Vitis vinifera L.) varieties cultivated in Turkey and their antiradical activity. Food Chem. 2008;109(2):426-430.

140. Llobera A, Cañellas J. Dietary fibre content and antioxidant activity of Manto Negro red grape (Vitis vinifera): pomace and stem. Food Chem. 2007;101(2):659-666.

141. Hwang JY, Shyu YS, Hsu CK. Grape wine lees improves the rheological and adds antioxidant properties to ice cream. LWT-Food Sci Technol. 2008;doi:10.1016/j.1wt.2008.03.008. 
